\title{
1,3-Dipolar cycloadditions: Applications to the synthesis of antiviral agents
}

\author{
Carmen Nájera, ${ }^{\mathrm{a}}$ and José M. Sansano ${ }^{\mathrm{a}}$ * \\ Received (in $X X X, X X X) X$ th $X X X X X X X X X 200 X$, Accepted $X$ th $X X X X X X X X X 200 X$ \\ ${ }_{5}$ First published on the web Xth $X X X X X X X X X 200 X$ \\ DOI: 10.1039/b000000x
}

Dedicated to Prof. Benito Alcaide on the ocassion of his $60^{\text {th }}$ birthday

In the present perspective it is described the advances and real possibilities of 1,3-dipolar cycloadditions as key step in the total synthesis of virus inhibitors. Azides, nitrones, and 10 azomethine ylides are the most appropriate 1,3-dipoles for the synthesis of privileged structures with the highest biological response against viruses.

\section{Introduction}

Newly emerging viral infections represent the major threat to human health. If we analyze the data concerning only the 15 killed people by the Influenza pandemics during the last century, we notice that this number goes beyond the deaths caused by other natural or man-made disasters. World Human Organisation $(\mathrm{WHO})^{1}$ alerts on the viral outbreaks announcing the spreading ways of the virus urging all governments to step 20 up surveillance.

Apart of the three more extended global virus infections namely human immunodeficiency virus (HIV, 35 millions approximately), hepatitis C virus (HCV, more than 190 millions) and influenza A and B viruses, ebola, Marburg,

25 dengue, yellow fever, nipah, enterovirus 71 and oncoviruses are the most dangerous viruses causing many human fatalities. $^{2}$ An additional drawback of these microorganisms is their fast mutation rates because a small genetic variation in an, a priori, inoffensive virus can originate a new strand with 30 increased capacity to cause disease (virus with increased virulence).

The vaccine development is an extremely effective strategy to protect people from specific virus infections. However, an appropriate vaccine cannot be developed before a virus can be 35 replicated in sufficient quantities to manufacture it. In fact, vaccines are very effective on stable virus but difficult to apply to rapidly mutagenic viruses such as influenza, HCV, etc. In this last situation, and obviously when the patient has already been infected, is when antiviral drugs became crucial. 40 An antiviral drug does not kill the virus, but acts by interfering one step of the viral replication process. This lowering in the replication frequency allows the body's immune system to destroy the virus using many natural defences.

45 Researchers working on strategies for developing antivirals have tried to attack viruses at every stage of their life cycles, namely attachment to a host cell, replication of viral components, assembly of viral components into complete viral particles and release of viral particles able to infect new hosts ${ }_{50}$ cells. The present and the future of these antiviral tools has been reported since the pharmacological point of view of pathogenic specific drugs such as amantidine, Tamiflu ${ }^{\circledR}$, and
Relenza ${ }^{\circledR}$ or ribavirin and interferons targeted against influenza or hepatitis C viruses, respectively. ${ }^{3}$ Unfortunately, 55 extensive data on their efficacy are not available and recent reports of drug resistance in patients infected with, for example, H5N1 raise serious concerns. ${ }^{4}$ So, new broadspectrum antivirals must be developed because the cost and the risk to a rapid drug resistance of the antivirals targeted 60 against single viruses are very elevated.

Genomics helps scientists to find targets at every viral stage and also provides crucial data for understanding the drugvirus effective interaction. Closely, the organic synthetic chemists are dedicating many efforts to design and prepare ${ }_{65}$ potential drugs once targets have been identified. From all of the resources, methodologies, reactions, etc., put into service of the preparation of antiviral agents, ${ }^{5}$ 1,3-dipolar cycloaddition (Hüisgen cycloadditions) ${ }^{6}$ constitute a powerful classical synthetic tool and one of the most productive fields 70 in modern organic chemistry. ${ }^{7}$

The reaction between 1,3-dipoles and alkenes or alkynes is very versatile allowing the presence of many functional groups in both components, namely 1,3-dipole I and dipolarophile II (Scheme 1). Yields of heterocycles III are 75 elevated with a few and easily removable impurities. The available precursors of dipole I can be, basically, divided in two groups: the allyl anion-type Ia such as nitrones, azomethine ylides, azomethine imines, carbonyl ylides and carbonyl imines, and the linear propargyl/allenyl anion-type ${ }_{80}$ Ib such as nitrile oxides, nitrile imines, nitrile ylides, diazoalkanes and azides (Figure 1).

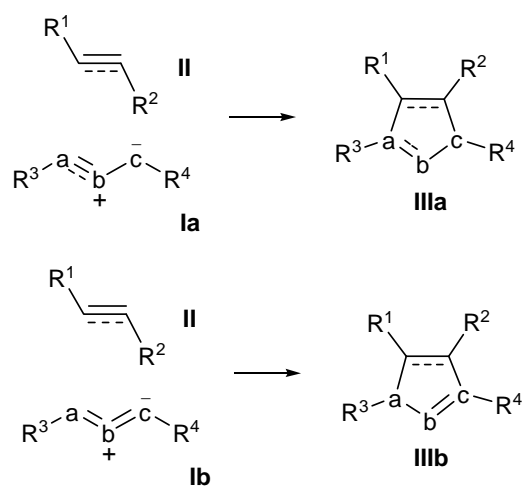

Journal Name, [year], [vol], 00-00 | 1 
Scheme 1. General 1,3-DCs of alkenes and alkynes.

This $[2 s+4 s]$ addition is stereoconservative (suprafacial) and stereospecific, and the six $\pi$-electrons participate in a 5 concerted or non-concerted reaction pathway controlled by the HOMO-LUMO interaction rules. ${ }^{7 \mathrm{c}, 8}$ The results of this elevated stereocontrol is the responsible of the high diastereo and regioselectivity (and also enantioselectivity in asymmetric synthesis examples) achieved in an impressive number of 10 heterocycles III. ${ }^{7,9}$ Another important feature of this transformation ${ }^{10,11}$ is that up to four stereogenic centres can be unambiguously generated in only one reaction step whether a diastereo- or enantioselective approach is performed.

The general interest of these broad series of cycloadducts ${ }_{15}$ III, as potential antiviral drugs, ${ }^{12}$ will be focussed on this perspective. For convenience, the examples will be classified on the basis of the involved 1,3-dipole, which are highlighted in a frame in the Figure 1.

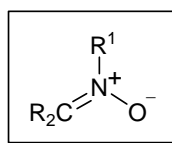

Nitrones<smiles>[R][N+]([R1])=[R]</smiles>

Azomethine imines

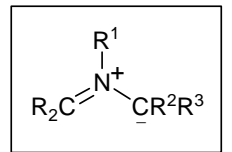

Azomethine ylides<smiles>[R]C=[O+][O-]</smiles>

Carbonyl oxides

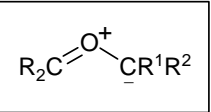

Carbonyl ylides<smiles></smiles>

Carbonyl imines

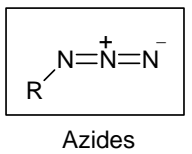

$$
\mathrm{R}-\overline{\mathrm{E}}^{+} \mathrm{N}-\mathrm{O}^{-}
$$

Nitrile oxides

$$
\mathrm{R}_{2} \mathrm{C}=\stackrel{+}{\mathrm{N}}=\mathrm{N}^{-}
$$$$
\text { Diazoalkanes }
$$

$$
\mathrm{R}-{ }_{\text {Nitrile imines }}^{+}-\overline{N R}^{1}
$$

$$
\mathrm{R}-\bar{\equiv}_{\text {Nitrile ylides }}^{+}-\overline{\mathrm{C}}^{1} \mathrm{R}^{2}
$$

Figure 1. Most important 1,3-dipoles in the synthesis of heterocycles III.

\section{Azides}

25

Organic azides $\mathbf{1}$ are readily available and potentially explosive compounds. Although the 1,3-DC between azides 1 and alkynes 2 (also with nitriles) ${ }^{7 \mathrm{~d}}$ is known for years, they are extensively employed since $2001 .^{11,13}$ The interest of this

30 process was the transformation of the purely thermal procedure $^{13}$ to a 1,3-DC catalysed by metal salts [mostly copper(I) salts], which dramatically accelerated the reaction even at room temperature (Scheme 2). ${ }^{14}$ Under these catalysed reaction conditions, the process becomes nearly solvent 35 insensitive, it shows an extremely high tolerance of functional groups and affords 1,2,3-triazoles $\mathbf{3}$ in excellent chemical yields with few by-products. ${ }^{15}$ 1,2,3-Triazoles are exceedingly stable to acidic and basic hydrolysis as well as severe reductive/oxidative conditions, and also capable of active 40 participation in hydrogen bonding as well as dipole-dipole and $\pi$-stacking interactions. The other important feature concerns the high regioselectivity achieved (1,4 addition over 1,5 addition) (Scheme $2 \mathrm{~b}$ ), unlike the thermal procedure that exhibits very poor regioselectivity (Scheme 2a). The resulting 45 1,2,3-triazole moiety ${ }^{16}$ is a likely candidate for small molecule drugs compatible with the side chain of all of the amino acids and the molecular dimensions of these heterocycles are somewhat similar to the amide bonds in terms of distance and planarity. These last two properties of $\mathbf{3}$ are closely related 50 with the successful interaction with enzymes or even DNA or RNA strands of the viruses in order to deter their proliferation.
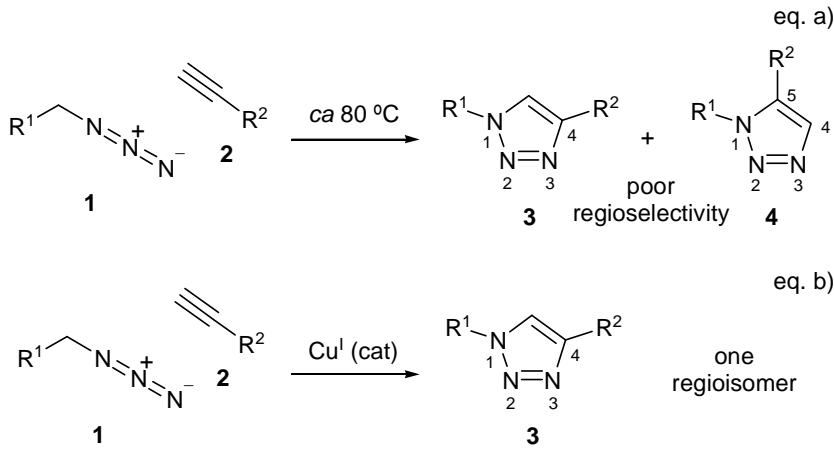

eq. b)

${ }_{55}$ Scheme 2. Cu-catalysed versus thermal 1,3-DC of azides and alkynes.

Many works focused on this 1,3-DC of azides and alkynes had, unfortunately, not marked biological activity. The most 60 productive results are shown as follows on the basis of the type of virus inhibited.

There is not vaccine or cure for HIV, and the most employed treatment consists of highly active antiretroviral therapy. Many derived compounds of AZT (a reverse ${ }_{65}$ transcriptase inhibitor) and others were prepared through a 1,3-DC between organic azides and alkynes with the objective of decreasing the viral replication and lowering their cytotoxicity (Figure 2). Nucleosidic molecules 5-7 and 9, and the non-nucleosidic structures $\mathbf{8}$ and $\mathbf{1 0}$ are examples of 70 triazole-containing entities able to inhibit HIV proliferation. One of the first contributions in this area was published in 1989, but nucleoside 5 showed moderate activity in HIV-1 infected cells. ${ }^{17}$ The same author used hydrazoic acid as 1,3dipole and a carbodiimide as dipolarophile, generated from $75 \mathrm{AZT}$, for the elaboration of compound $\mathbf{6}$, which also exhibited moderate activity against HIV $-1{ }^{18}$ The series of products 7 were prepared and tested as antiviral HIV agents, the most active being $\mathrm{R}^{1}=\mathrm{Bu}^{\mathrm{t}}(\mathrm{Me})_{2} \mathrm{Si}-, \mathrm{R}^{2}, \mathrm{R}^{4}=\mathrm{H}, \mathrm{R}^{3}=\mathrm{CONMe}_{2} .{ }^{19}$ Phosphasugar $N$-nucleoside derivatives were prepared to be 80 antiviral agents but any data about biomedical studies was described. ${ }^{20}$ Compound 9 showed an interesting activity against wild type HIV-1 and mutant strains, which is comparable with other nucleoside reverse transcriptase inhibitors such as MKC-442. ${ }^{21}$ Molecules 5-9, as surrogates of ${ }_{85} \mathrm{AZT}$, function as analogues for thymidine and this means that AZT and its mimetics, have the same shape as it, and therefore it can be incorporated into the developing nucleic acid in place of a thymidine molecule. The phosphate group attached to thymidine or AZT forms a bond with the 3'-OH 90 group of the preceding nucleotide in the developing DNA chain. When thymidine is incorporated into the DNA chain, 
its $3^{\prime}-\mathrm{OH}$ becomes the binding site for the next nucleotide's phosphate group. However, AZT and its mimeics lack the $\mathrm{OH}$ functional group that is necessary to form a bond with the next nucleotide; in its place is an azido $\left(-\mathrm{N}_{3}\right)$ group. Because 5 the azido group cannot form a bond with a phosphate group, no additional nucleotides can be added once AZT is incorporated into the DNA chain. Hence, reverse transcription stops after AZT is incorporated.

The non-nucleosidic product $\mathbf{1 0}$ (obtained by a 10 conventional 1,3-DC) revealed to be an important inhibitor of the wild type HIV1 $\left(\mathrm{IC}_{50}=6 \mathrm{nM}\right)$ and also of several mutant strains. ${ }^{22}$ This molecule inhibit certain proteases, which are enzymes used by the viruses to cleave nascent proteins needed for the final assembly of new virions, and their inhibition also 15 prevent the viral replication. The authors observed that the incubation of the azide $\mathbf{1 1}$ and alkyne $\mathbf{1 2}$ in the presence of the HIV-1-PrSF-2WTQ74-Pr protease (henceforth simply denoted SF-2-Pr, $15 \mu \mathrm{M}$ ) in 2-morpholinomethanesulfonic acid (MES; $0.1 \mathrm{M}) \mathrm{NaCl}(0.2 \mathrm{M})$ buffer solution at $23{ }^{\circ} \mathrm{C}$ for $24 \mathrm{~h}$, the 20 acceleration of the reaction (ten fold) occurred enhancing the regioisomeric ratio in favour of the 1,4-isomer 10 (18:1). The target protease itself acted as a template for the reaction (Scheme 3) that forms its own inhibitor. ${ }^{23}$ Paragraph removed here.<smiles>COC(C)c1cn([C@@H]2C[C@H](n3cc(C)c(=O)[nH]c3=O)O[C@@H]2CO)nn1</smiles><smiles>[R]Nc1nnnn1[C@@H]1C[C@H](n2cc(C)c(=O)[nH]c2=O)O[C@@H]1CO</smiles><smiles>[R20]C[C@H]1O[C@@H](n2nnc([R])c2[R])[C@H](O)[C@]12OO[Si]O2</smiles><smiles>[R]c1nnn(C2[R]([H])([H])CC[C@@]2([R])O)c1[R]</smiles><smiles>CCc1c(Cc2cc(C)cc(C)c2)n(COCc2cn([C@@H]3C[C@H](n4cc(C)c(=O)[nH]c4=O)O[C@@H]3CO)nn2)c(=O)[nH]c1=O</smiles><smiles>COc1ccc(S(=O)N(CC(C)C)C[C@H](O)[C@H](Cc2ccccc2)n2cc(COC(=O)N[C@H]3c4ccccc4C[C@H]3O)nn2)cc1</smiles>

10

Figure 2. Important inhibitors of HIV virus.<smiles>C#CCOC(=O)N[C@H]1c2ccccc2C[C@H]1O</smiles>

${ }_{30}$ Scheme 3. Synthesis of product 10.

A recent contribution demonstrated that compound $\mathbf{1 0}$ retains high affinity for both wild-type and $\mathrm{PR}_{6 \mathrm{x}}$ multidrug resistant (MDR) protease viruses as the result of interactions with selected 35 residues and maintenance of hydrogen bonding to main chain 
atoms. Thus, compound $\mathbf{1 0}$ binds to the protease that promotes multidrug resistance, the triazole moiety forms a precise hydrogen bonding network and the carbamate accepts a hydrogen bond from the amide of Gly48. Both of these interactions feature 5 a conserved element of protease structure. The 1,3-DC of modified starters $\mathbf{1 1}$ and $\mathbf{1 2}$ will also allow the evaluation of whether such changes improved the antiviral performance against newly appearing multidrug-resistant viruses. ${ }^{24}$

The employment of the catalysed 1,3-DC of azides and 10 alkynes contributes to the formation of novel templates based on oligosaccharide $^{25}$ or peptide ${ }^{26}$ clusters. The incorporation of several units of triazole derivatives on these natural or synthetic polymers is responsible of their increased binding affinity and antiviral activity against multiple strands of HIV-1. This strategy

15 allows to optimise the size and nature of the substituents in both dipole and dipolarophile to achieve the best efficiency with the smallest structure. For example, the successful construction of the fully synthetic immunogens that contain novel oligosaccharide clusters has laid the foundation for further immunisation studies 20 in animals to evaluate whether the vaccine candidates are able to elicit carbohydrate-specific neutralising antibodies against HIV, ${ }^{25}$ constituting a very exciting research area. Particularly, it is known that sugar chains were crucial for high affinity binding to the antibody 2G12. This human monoclonal antibody potently 25 and broadly neutralizes primary and T-cell line-adapted clade B strains of HIV-1 in a peripheral blood mononuclear cell-based assay and inhibits syncytium formation in the AA-2 cell line.

Worldwide extended influenza viruses caused seasonal epidemic. Vaccinations against influenza are usually given to 30 people, the most common being trivalent influence vaccine (TIV). It contains purified and inactivated material for two influenza A viruses subtype and one influenza B strain. Spite of this advantage, several specific antiviral drugs have been designed to inhibit the most aggressive influenza virus types. The 35 most active synthetic compound corresponded to the series of non-nucleosidic molecules $\mathbf{1 3}$, whose structure is very similar to zanamivir. In fact, compound $\mathbf{1 3}\left[\mathrm{R}^{1}=\mathrm{CH}(\mathrm{OH}) \mathrm{C}_{2} \mathrm{H}_{5}, \mathrm{R}^{2}=\mathrm{H}\right)$ is almost as active as zanamivir against avian influenza virus (AIV) $\mathrm{H} 5 \mathrm{~N} 1 .{ }^{27}$ In this work molecular modelling provided very reliable 40 information about the binding model between inhibitors and neuraminidase, which was in a good agreement with the observed in vivo activity of the inhibitors. To better understand the activity discrepancy of synthesised new inhibitors and zanamivir, the study was based on the crystal structure of neuraminidase45 inhibitors derived from docking simulation. Whilst carboxylic acid group of zanamivir formed strong hydrogen bonds with two arginine residues $(\operatorname{Arg} 118, \operatorname{Arg} 371)$ in the S1 region and five hydrogen bond interactions in $\mathrm{S} 2$ region through the guanidinyl moiety, inhibitor $13\left[\mathrm{R}^{1}=\mathrm{CH}(\mathrm{OH}) \mathrm{C}_{2} \mathrm{H}_{5}, \mathrm{R}^{2}=\mathrm{H}\right)$ moved up 50 forming exclusively a hydrogen bond with residue $\operatorname{Arg} 152$ in the S2 region. Large substituents with different electronic properties of other molecules $\mathbf{1 3}$ could not be accommodated in the subsite S2, and hence the six membered ring flipped resulting in a drop of inhibitory activity. ${ }^{27}$

55<smiles>[R]C(=O)C1=C[C@@H](n2cc([R])nn2)[C@H](N)[C@H]([C@H](O)[C@H](O)CO)O1</smiles>

13

Figure 3. Compounds inhibitors of influenza virus.

The neuraminidase enzymes (also called sialidases) are 60 glycoside hydrolase enzymes that promote the mobility of virus particles through the respiratory tract mucus and in the elution of virion progeny from the infected cell. In this line, multivalent 1,3,5-triazine or sialic acid containing-scaffolds have been designed incorporating structures 13, which have ${ }_{65}$ shown to have stable structures in solution and well suited for functionalisation with antiviral relevant ligands versus influenza viruses. $^{28,29}$

Ribavirin and their analogues are widely used for treating $\mathrm{HCV}$ infections. Searching for a highest inhibition of the ${ }_{70} \mathrm{HCV}$ and lowest cytotoxicity, 1,2,3-triazole derivative families such as $\mathbf{1 6}$ and $\mathbf{1 7}$ were prepared. Although the antiviral activity of their dibenzoylated surrogates was moderate, it was noticeable the high regioselectivity achieved with $\mathrm{Cu}^{\circ} / \mathrm{CuSO}_{4}$ couple (favouring the 1,4-regioisomer), and 75 the reverse regioselectivity (favouring the 1,5-regioisomer) obtained when $\mathrm{Cp}{ }^{*} \mathrm{RuCl}\left(\mathrm{PPh}_{3}\right)_{2}$ complex was employed. Protected $\beta$-azidoribose 14 reacted with alkynes $\mathbf{1 5}$ under a copper(I)-catalysed 1,3-DC affording triazoles $\mathbf{1 6}$ in very good yields and with total 1,4-regioselectivities (>99:1)

80 (Scheme 4). Highest conversions and chemical yields were generated upon microwave radiation, in the presence of the above mentioned ruthenium catalyst, furnishing compound $\mathbf{1 7}$ with a high $1,5: 1,4$ regioisomeric ratio (up to $97: 3$ ). ${ }^{30}$

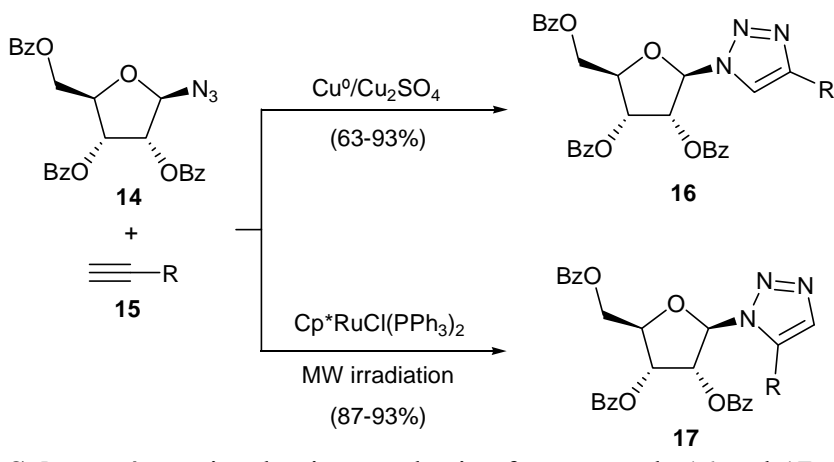

Scheme 4. Regioselective synthesis of compounds $\mathbf{1 6}$ and $\mathbf{1 7 .}$

There is currently substantial interest in the use of nucleic acids for modifying gene expression for therapeutic purposes. 90 The lipid-conjugated oligonucleotides via 1,3-DC potentiates the cellular uptake of oligonucleotides and allows their intracellular delivery. These non-toxic lipid conjugates $\mathbf{1 8}$ (Figure 4) efficiently inhibit HCV internal ribosome entry site-mediated translation in human hepatic cells. The specific 95 target was the subdomain IIId of the mentioned internal ribosome entry site at the 5 ' end of the viral RNA. ${ }^{31}$ 
Through a similar mechanism, oligonucleotides bearing the p-tolyl-group as substituent of the both oxygen atoms in $\mathbf{1 9}$ afforded better interactions with the virus. In addition, this protecting group decreased notably their cytotoxicity. 5 Particularly active were the newly synthesized compound 19 bearing a 6-chloro-7-deazapurine or 2-amino-6-chloro-7deazapurine (Figure 4$)^{32}$

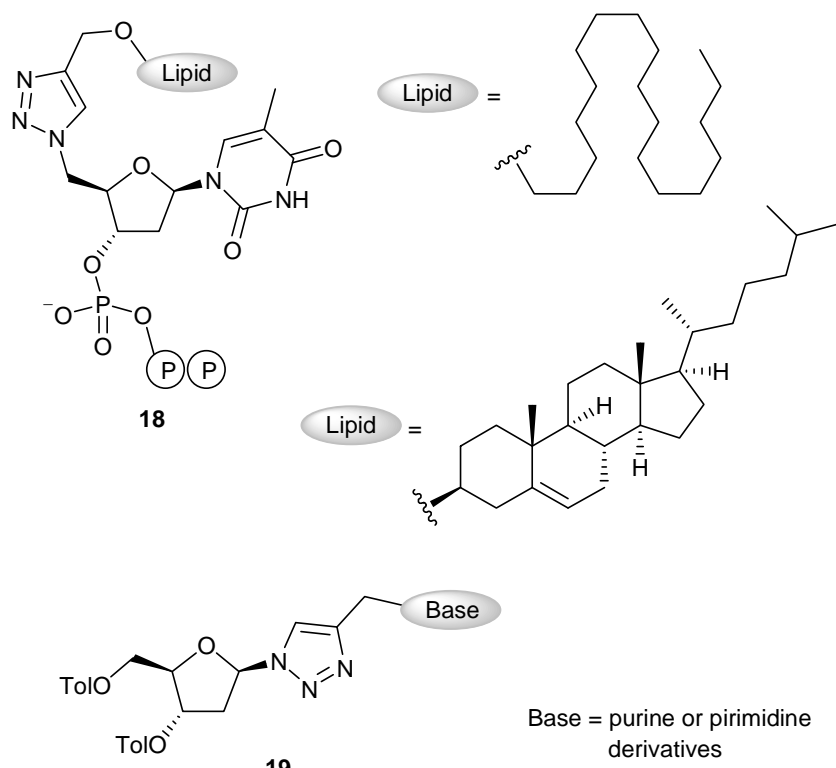

${ }_{10}$ Figure 4. Antivirals against HCV.

Less aggressive hepatitis B virus (HBV) has also been moderately inhibited by 1,2,3-triazoles 20 and 21 (Figure 5) obtained as cycloadducts by reaction of 1-propargyl 15 pyrimidines with 5-azido-5-deoxyribofuranoside or 1-azido-1deoxytetra-O-acetylglucose. The most active structures were the pyrimidine derivatives rather than the pyridine analogues, obtained from 1-propargyl pyridinium salts. Presumably, this anti-HBV therapy was originated by inhibition of viral 20 replication degrading HBV pregenomic RNA and message RNAs. ${ }^{33,34}$<smiles>[R]n1cc(Cn2cc(C)c(=O)nc2SC)nn1</smiles>

20<smiles>[2H][C@H]1C[C@@H](OC)[C@@H](O)[C@@H]1O</smiles>

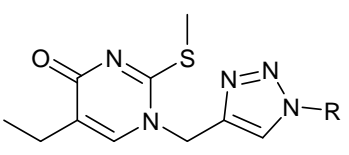

21<smiles>CC1O[C@H](CO)[C@@H](O)[C@H](O)[C@H]1O</smiles>

Figure 5. Bioactive compounds against $\mathrm{HBV}$.

Acyclonucleosides 22 and 23, with the alkylating chain of acyclovir, were prepared and evaluated against tuberculosis virus showing moderate activity. ${ }^{35,36}$ Carbonucleosides $\quad 24$ gave very low inhibition levels of small pox, vaccinia or 30 cowpox viruses. ${ }^{37}$ However, 1,2,3-triazole carbanucleosides
25 and more specifically iodide 26 (Figure 6) exhibited an elevated inhibitory potential against thymidine kynase varicella-zoster virus $\left(\mathrm{TK}^{+} \mathrm{VZV}\right){ }^{38}$

Another applications of 1,3-DC of azides and alkynes or 35 alkenes concerns the construction of biomolecular prototypes. For example, it was observed that the degradation of the viral particles occurred during the 1,3-DC of the corresponding alkyne, and the azide derived from the icosahedral cowpea mosaic virus (CPMV). Molecules 27 (Figure 6) incorporate an 40 aliphatic chain with a 1,2,3-triazol unit. This carbonous structure is bonded to the virus through an amino group of the native reactive lysines, and genetically inserted cysteines of the protein subunits arranged helically around genomic single RNA strand. ${ }^{39}$ This binding caused degradation or variation of 45 the stability of the viral peptides, which has been considered of great interest for future investigations. ${ }^{39,40,41}$<smiles>[R]c1ncnc2c1cnn2Cc1cn(COCCO)nn1</smiles><smiles>[R]c1ncnc2c1cnn2Cc1cnnn1COCCO</smiles>

23<smiles>[R]c1cn(C2CC(CO)(CO)C[C@H]2O)nn1</smiles>

24<smiles>[R9]C[C@@H]1C=C[C@H](n2cc([Al])nn2)C1</smiles>

25<smiles>[R6]C[C@H]1C[C@@H](I)[C@H](n2cc([Al])nn2)C1</smiles>
26

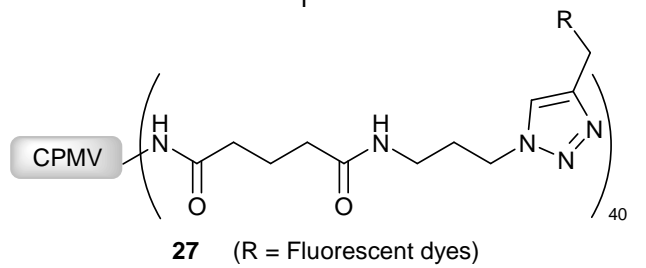

Figure 6. Several antiviral inhibitors prepared by 1,3-DC of ${ }_{50}$ azides and alkynes.

Although they are not considered antiviral agents, there are another contributions dealing with the synthesis of very interesting useful molecules for the study of biomolecular 55 recognition, binding mecanisms, etc. For example, the synthesis of radiolabelled peptides $\left({ }^{18} \mathrm{~F}\right.$ or $\left.{ }^{11} \mathrm{C}\right)$, incorporating 1,2,3-triazole units, have been used as diagnostic agents, for example, as radiopharmaceuticals for several purposes, and also served as a vector to direct a small drug to the virus. ${ }^{42}$ As $60 \mathrm{well}$, azides and alkynes are easily transformed in the corresponding 1,2,3-triazoles in the synthesis of ligands for the preparation of antiviral drugs, ${ }^{43}$ in the preparation of sensors on oligo- or poly(ethylene glycol) films on silicon surfaces, which possessed an structural portion capable of 
being recognised by a biological specimen (included viruses), ${ }^{44}$ and finally, in the elaboration of cross-linked polymeric multilayers, interesting for the fields of directed drug delivery towards viruses and tissue engineering. ${ }^{45}$

\section{Nitrones}

Nitrones 28 or azomethine oxides were first prepared by 10 Beckman in 1890 . Their chemistry is hugely varied, ${ }^{46}$ but it is ultimately dominated by their use as 1,3-dipoles for cycloaddition reactions. ${ }^{7,47}$ The most common 1,3-DC involving nitrones, is the formation of isoxazolidines $\mathbf{3 0}^{48}$ using alkenes $\mathbf{2 9}$ as dipolarophiles (Scheme 5), although other 15 different multiply bonded systems may also be used such as alkynes, allenes, isocyanates, nitriles, thiocarbonyls, etc. The isoxazolidine adduct $\mathbf{3 0}$ contains up to three new stereogenic centres and the reaction products can be predictable according to the experiences, results and frontier molecular orbital 20 (FMO) theory. ${ }^{7 \mathrm{c}}$ The E/Z-interconverting nitrones $\mathbf{2 8}$ reacted with electron-rich alkenes 29a through a first nitrone oxygen atom attack to the $\alpha$-position of the electron-rich alkene, however, this oxygen atom react with the $\beta$-position of the electron-poor alkenes 29b (Scheme 5). Often, diastereomeric 25 pairs of exo- and endo-adducts are formed under thermal conditions. However, steric hindrance is of importance to control the approach of the alkenes towards the nitrones. Operating under metal-catalysed or organocatalysed processes, run at lower temperatures, the overall control of the 30 absolute configuration of each stereogenic centre can be achieved. The diastereoselective processes are also efficient to furnish optically enriched heterocycles. ${ }^{7 \mathrm{~d}}$

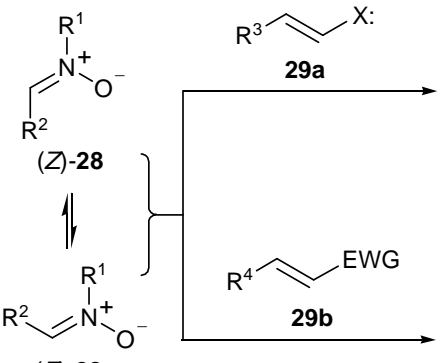

(E)-28

* = Stereogenic centre
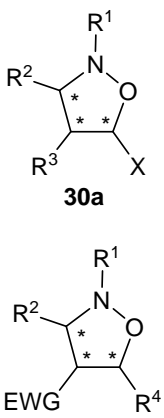

$30 \mathrm{~b}$

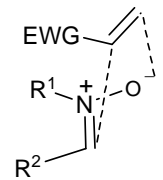

endo-approach

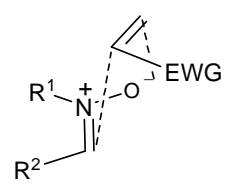

exo-approach
${ }_{35}$ Scheme 5. General 1,3-DC of nitrones.

This cycloaddition has been applied (in lesser extension than the above mentioned azides) to the elaboration of inhibitors of RNA viral strands. For example, it was found

40 that derivatives of natural nucleic acids play an important role in current chemotherapy as potent and selective antiviral agents in AIDS treatment. The ribose ring surrogates depicted on Figure 7 are considered as active inhibitors of HIV. Especially active was product ADF 37, which was a good 45 inducer of cell death by apoptosis on Molt-3-cells, a continuous line of human thymphoblasts. ${ }^{49}$ In previous works some isoxazolidines 31-35 (also called azadideoxynucleosides) were synthesized through the same route with identical objective, but the inhibition of HIV was only 50 moderate..$^{50,51,52,53}$ In all cases, products $31-37$ were obtained through the 1,3-DC of the nitrone with the corresponding $\mathrm{N}$ vinylpurine or $N$-vinylpyrimidine heating the mixture for $4 \mathrm{~h}$ approximately, obtaining only the desired regioisomer. Azanucleosides can act as intercaling drugs avoiding the ${ }_{55}$ reverse transcription or can induce a different new doublestranded RNA (dsRNA), which effectively inhibit the expression of the HIV genes.<smiles>Cc1cn(C2CCNO2)c(=O)[nH]c1=O</smiles>

31 (ADT)<smiles>c1ccc(CN2CCC(n3cnc4c(NC5(c6ccccc6)c6ccccc6Oc6ccccc65)ncnc43)O2)cc1</smiles><smiles>Nc1nc2c(ncn2C2CCNO2)c(=O)[nH]1</smiles>

33 (ADG)<smiles>Nc1ccn(C2CCNO2)c(=O)n1</smiles>

$34(\mathrm{ADC})$
35 (5-Me-ADC)<smiles>Cc1cn(C2CCNO2)c(=O)nc1N</smiles>

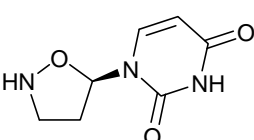

36 (ADU)

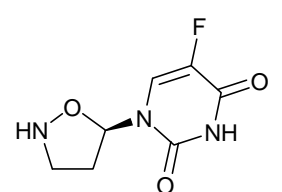

37 (ADF)
Figure 7. Inhibitors of HIV from nitrones and $N$-vinylpurines or $N$-vinylpyrimidines

The herpes simplex virus (HSV) type 1 and 2 are very ${ }_{65}$ extended viruses causing different pathologies. The inhibition of them can be achieved by the use of molecule 38a $(B=5$ fluorouracyl) rather than other isoxazolic nucleosidic bases $\mathbf{3 8}$ (Figure 8). Again, $N$-vinylpurines or $N$-vinylpyrimidines were employed as dipolarophiles. ${ }^{54}$ Bicyclic $N, O$-nucleoside 70 analogues 39 showed an interesting inhibition of HSV-1 replication in the range of $100 \mu \mathrm{M}$. The particular conformation of 39 reduces the probability of puckering interconversion, which justify strongly the conserved DNAlike shape and therefore they could be considered for 75 optimisation studies for designing more potent HCV reverse transcriptase inhibitors. ${ }^{55}$ Phosphonated carboxylic-2' - -oxa-3'azanucleosides 40 were obtained according to the already mentioned thermal 1,3-DC. The nitrone-phosphonate and vinyl acetate followed by the attack of the purine or 80 pyrimidine moiety to the anomeric carbon. The resulting nucleosidic derivatives $\mathbf{4 0}$ were tested and low levels of cytotoxicity were detected, but most importantly was their activity as inhibitors of reverse transcriptase in virus. In fact, it was as powerful as AZT and one of the most effective 85 known inhibitors of the hepatitis B virus. ${ }^{56}$ The ability of the 
newly synthesized compounds to inhibit retroviral RNAdependent DNA polymerase (reverse transcriptase) activity was determined by means of a novel, cell-free assay, originally developed for a preliminary screening of potential 5 inhibitors of reverse transcriptase. In this assay, RNA isolated from stable transfectants, expressing constitutively the glycoprotein D (gD) of HSV-1, was used as template for the reversal transcriptase activity of commercial avian myeloblastosis virus reverse transcriptase (AMV-RT) and 10 moloney murine leukemia virus reverse transcriptase (MLVRT) ${ }^{56}$ The postulated mechanism of the inhibition of the reverse transcriptase was identical to the already described for AZT surrogates (above).

The homologous series of azanucleosides $\mathbf{4 1}$ were prepared 15 by the same chemical route but using a microwave radiation $(100 \mathrm{~W}, 20 \mathrm{~min})$ for the obtention of a 1.8:1 endo:exo ratio of the precursor isoxazoline in $65 \%$ yield. Their activity as inhibitors of HIV or HBV was moderate and lower than homologous structures 40. However, compounds 41 20 contributed to the research of the structural features, which concur to determine the biological activity of the $N, O-$ nucleoside system.

The insertion of nucleotides in the growing nucleic acid chain, operated by polymerases, is assisted by bivalent 25 metallic ions that facilitate the transfer of nucleotide units. It was speculated that the nitrogen atom of the heterocycle would facilitate the breaking between $\mathrm{P}_{\alpha}$ and $\mathrm{P}_{\beta}$ in the nucleotide triphosphate structure and, in this way, allows the transfer of a diphosphoryl or a nucleotidyl group. The 30 nitrogen atom is probably responsible for metal-ion coordinations and, in this context, while the distance $\mathrm{P}_{\alpha}-\mathrm{N}_{3}$ in compounds 40 promotes the formation of 6-membered chelates, for compounds 41 the distance $\mathrm{P}_{\alpha}-\mathrm{N}_{3}$ is not compatible with anyone stable 7-membered chelate and, 35 consequently, any antiviral activity is forbidden. ${ }^{57}$

Compound 42, obtained by reaction of the corresponding nitrone and allyl alcohol at $160{ }^{\circ} \mathrm{C}$, was active against the bunyavirus punta toro virus (PTV) for which cytotoxic/antiviral ratio was virtually 10 -fold. This PTV is 40 one of eight members of the family Bunyaviridae, which produce disease in man through accelerated apoptosis of hepatocytes in vivo. Preliminary docking studies of this compound $\mathbf{4 2}$ to the B-DNA fragment d(CGCAATTGCG) show that it preferentially intercalates in the DNA AT region, 45 and the resulting complex is further stabilised by a hydrogen bond between the hydroxyl group of the hydroxymethyl moiety and an oxygen of a phosphate group. ${ }^{58}$

Whilst potentially inhibitors of virus endo- and exo-43 are currently being evaluated in vivo, ${ }^{59}$ the formation of isoxazole ${ }_{50} \mathbf{4 4}$ was the key step in the total synthesis of racemic BCX1812(RWJ-270201) 45. The 1,3-DC was performed at room temperature in the presence of sodium hypochlorite with an isolated yield of $61 \%$. Compound $\mathbf{4 5}$ is in clinical phase due to its notable selectivity and potency against neuraminidase of 55 a wide range of influenza $\mathrm{A}$ and $\mathrm{B}$ viruses. The strong interaction between $\mathbf{4 5}$ and the S2 region of neuraminidase ensures a high inhibition. However, this agent may not confer ideal therapeutic characteristics due to several side effects.
The establishment of a practical, efficient, and versatile 60 synthetic route would contribute to further structure-activity relationship (SAR) studies needed for the development of safe and potent neuraminidase inhibitors. ${ }^{60}$<smiles>CN1[B]C(C2CCC2)CC1(CO)CO</smiles><smiles>CN1OC(n2cc(F)c(=O)[nH]c2=O)CC1(CO)CO</smiles>

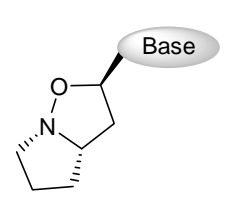

39

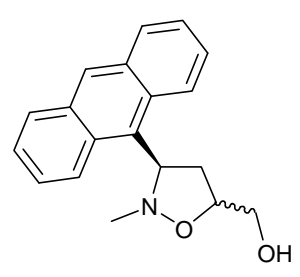

42

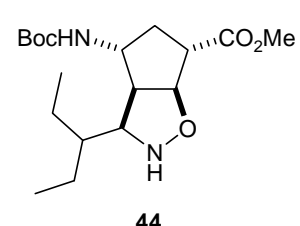

44<smiles>CCOP(=O)(C[C@@H]1C[C@H](CC2(Br)CC2)ON1C)OCC</smiles>

40

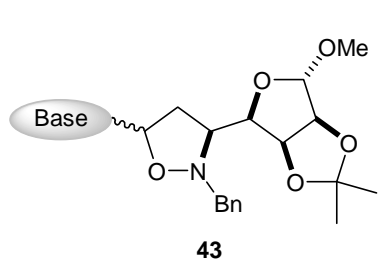

43<smiles>CCOP(=O)(CC[C@@H]1C[C@H](CC(C)(C)C)ON1C)OCC</smiles>
41
Base $=$ purine or pyrimidine derivatives

${ }_{65}$ Figure 8. Thermally-generated isoxazolines with noticeable inhibition of different virus types.

The diastereoselective synthesis of $N, O$-nucleosides $\mathbf{4 8}$ was achieved in $41 \%$ yield by the reaction of intermediate nitrone 70 47, obtained from $N$-ribosylhydroxylamine 46, with $N$ vinylpurines or $N$-vinylpyrimidines. The diastereomeric ratios were moderate (1.5:1) furnishing compound 48a as major stereoisomer (Scheme 6). Nucleoside analogues 48 exhibited low levels of cytotoxicity, however, heterocycles 49a and 49b 75 (base = fluorouracil, FU) caused very fast cell death by apoptosis in lymphoid cells. These investigations opened new perspectives on their possible use as therapeutic antiviral agents. To obtain further information on the mechanisms regulated by AdFU-induced apoptosis, the possible 80 involvement of the caspase-cascade was confirmed after culture tests and calorimetric assays. ${ }^{61}$ 
<smiles>[R9]C[C@H]1O[C@H](NO)[C@@H]2OC(C)(C)O[C@H]12</smiles>

46

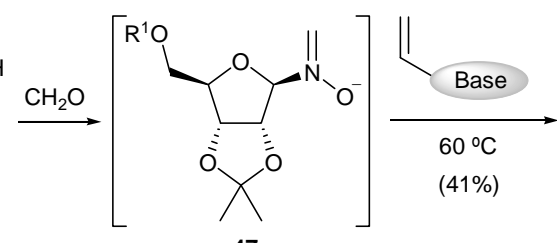

47
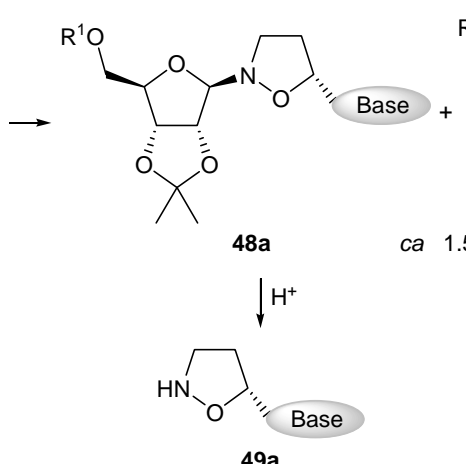

ca $1.5: 1$
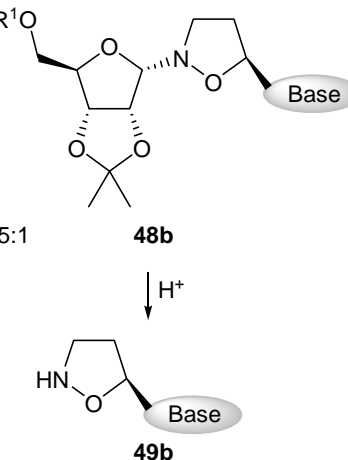

Base $=$ purine or pyrimidine derivatives

$\mathrm{R}^{1}=\mathrm{Bu}^{\mathrm{t}}\left(\mathrm{Pr}^{\mathrm{i}}\right)_{2} \mathrm{Si}$

Scheme 6. Synthesis of antiviral compounds $\mathbf{4 8}$ and $\mathbf{4 9}$

\section{${ }_{5}$ 4. Azomethine ylides}

Azomethine ylides are 1,3-dipoles very frequently generated in situ, by a thermal 1,2-prototropy shift in iminoesters $\mathbf{5 0}$ or by a base-assisted formation of a metallo-dipole also from $\mathbf{5 0}$. 10 Although many other methods are known, the metallo-dipole route is the most employed due to its simplicity and the mildness of the reaction conditions required. ${ }^{7,62}$ According to the stereochemical point of view, metallo-dipoles 52 are crucial species because its geometry is perfectly controlled, 15 which allows to obtain highly diastereoselective 1,5-cisadducts. The frontier orbital theory (FOT) explains the high regioselectivity and very important endo/exo diastereoselections achieved in the preparation of proline derivatives $53^{63}$ (Scheme 7), following the identical dipole20 dipolarophile approach depicted for nitrones (see Scheme 5). All this features are a solid support to catalytic enantioselective processes ${ }^{64}$ determining unambiguously the absolute configuration of up to four stereogenic centres of pyrrolidines 53. ${ }^{65}$ The 1,3-DC using azomethine ylides is only 25 productive when electron-deficient alkenes are employed.

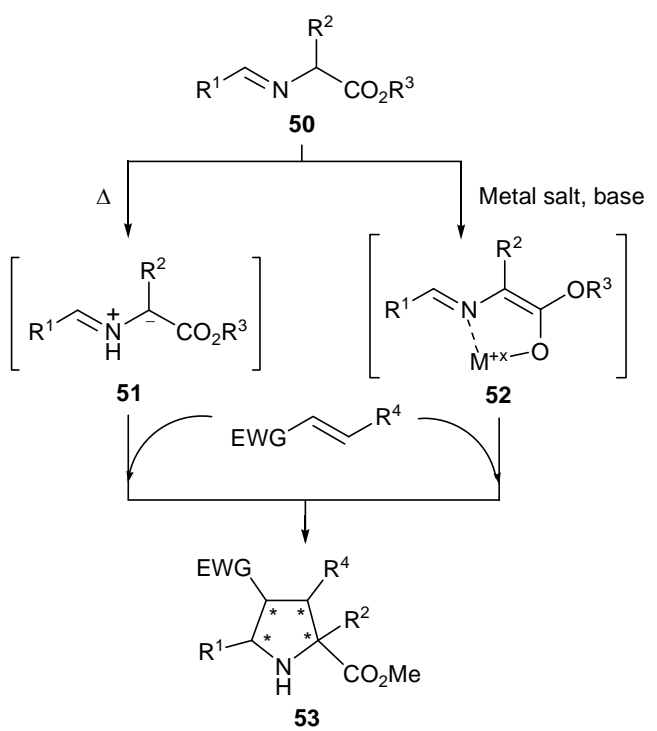

Scheme 7. General 1,3-DC using azomethine ylides.

30 One of the most relevant applications of these cycloadditions is the generation of the key intermediate in the preparation of potent and promising inhibitors of the HCV polymerase. This enveloped single-stranded RNA virus (belonging to the Flaviviridae family) is present in six major 35 genotypes in the world industrialized nations, genotype 1 being the most prevalent, followed by genotype 2 and 3 . Inside of the infected hepatocyte, structural E1 and E2 and non-structural proteins such as NS2, NS3 (which bears serine proteinase, helicase, and NTPase activities), NS4A, NS4B, 40 NS5A (regulators of RNA replication), and NS5B (the RNAdependent RNA polymerase) are generated. ${ }^{66,67}$ So, their high replication rates (billions of copies per day) can be drastically suppressed by the inhibition of the NS5B RNA-dependent RNA polymerase enzyme, which is the primary target for oral ${ }_{45}$ antiviral agents $\mathbf{5 4 - 5 7}$ (Figure 9). ${ }^{68}$<smiles>CC(C)C[C@]1(C(=O)O)C[C@H](C(=O)O)[C@H](c2cccs2)N1C(=O)c1ccc(C(F)(F)F)cc1</smiles>

54<smiles>COC[C@H]1C[C@](CC(C)C)(C(=O)O)N(C(=O)c2ccc(Br)c(OC)c2)[C@H]1c1nccs1</smiles>

Figure 9. Proline inhibitors of the HCV.<smiles>CC(C)C[C@]1(C(=O)O)C[C@H](C(=O)O)[C@H](c2nccs2)N1C(=O)c1ccc(Br)cc1</smiles>

55<smiles>COC[C@H]1C[C@@](Cn2cccn2)(C(=O)O)N(C(=O)c2ccc(Br)c(OC(C)(C)C)c2)[C@H]1c1nccs1</smiles>

50 The preparation of racemic $N$-acylpyrrolidine $\mathbf{5 4}$ was accomplished by means of concerted thermal 1,3-DC between 
supported Wang resin-azomethine ylides 58 and tert-butyl acrylate (Scheme 8). The pure enantiomers were separated by preparative chiral HPLC, after amidation and hydrolysis of both esters groups. ${ }^{69}$ In this way, many $N$-acyl pyrrolidines 5 were designed finding heterocyclic compound $\mathbf{5 7}$ as the most promising candidate to help infected people.

The potent activity of these series of products was correlated with the binding site identification and genotypic profiling of $\mathrm{HCV}$ polymerase inhibitors. ${ }^{70}$ The search for 10 hepatitis $\mathrm{C}$ virus polymerase inhibitors has resulted in the discovery of several non-nucleoside binding pockets. The shape and nature of these binding sites differ across and even within diverse hepatitis $\mathrm{C}$ genotypes. These differences confront antiviral drug discovery with the challenge of 15 binding compounds that are capable of inhibition in variable binding pockets. It was demonstrated that the recombinant P495L, M423T, M414T, and S282T mutant enzymes could be used to identify the binding site of the acyl pyrrolidine inhibitors. For these prolines it was found that Phe415 is 20 crucial for genotype 1a coverage. Hydrogen bonding and contacts with the polypeptide backbone are rare. To best adapt to highly variable binding sites of NS5B, small molecules ideally used hydrophobic interactions with the residue placed at the $\alpha$-position of the heterocycle. The hydrophobic 25 arilcarbonyl group must be important in order to ensure or increase the permeability through the lipidic membranes. This property is transformed in good replicon potency and good pharmaco-kinetics for future developments of new drugs. The $\alpha$-epimers are more potent than the corresponding $\beta$ 30 epimers. $^{70}$

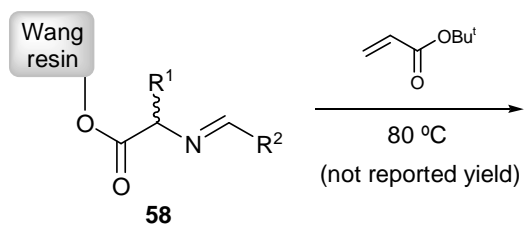

58

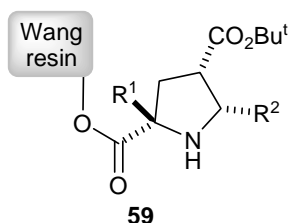

54

Scheme 8. Synthesis of the racemic endo-54 35

The first synthesis of racemic product 55, and another derivatives including compound $\mathbf{5 4}$ was achieved in several steps using as the key reaction the silver(I) or lithiummetalloazomethine ylide, generated from iminoester $\mathbf{6 0}$ under 40 basic conditions and tert-butyl acrylate. The resulting cycloadduct 61 was obtained in $67 \%$ yield through a nonconcerted mechanism (Scheme 9). The enantiomeric samples were isolated from semi-preparative chiral HPLC. A small modification on the side chain of the heterocycle (amido 45 group instead of carboxylic group) gave raise to product $\mathbf{6 2}$, which in its $(+)$-form exhibited superior activity in both the enzyme and the replicon assays (Scheme 9). ${ }^{71}$

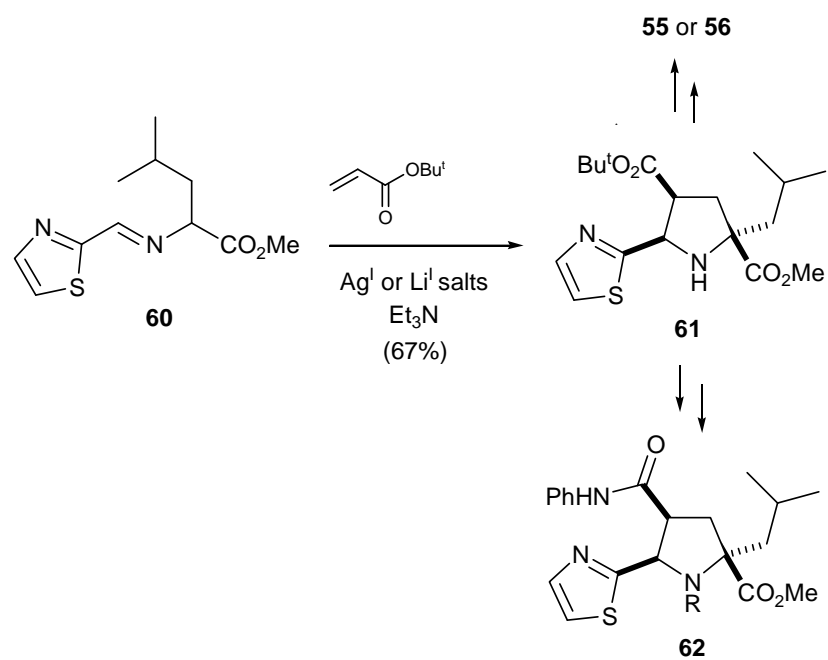

${ }_{50}$ Scheme 9. Synthesis of several racemic HCV inhibitors.

Molecule 56 (3082) was obtained through the analogous key intermediate $\mathbf{6 1}$ (Scheme 9). These 3-methoxyarylamides had superior solubility properties and lower molecular weights 55 than other precedent antiviral agents. In this occasion, to resolve the racemic mixtures of compound 61, $(R)-(-)-1,1$ 'binaphthyl-2,2'-diyl-hydrogen phosphate was employed providing the required diastereomeric salt in good yield and excellent enantiomeric excess at the end of the process $60(98.8 \%)$. In this work, a comparison of the X-ray structures of dicarboxylic acid $\mathbf{5 5}$ and the binding site of the HCV polymerase was surveyed. The bulkier tert-butyl substituent on the benzamide caused movement in the side chain of Leu384 allowing inhibitors to bind deeper into the pocket an ${ }_{65}$ increase their antiviral power. ${ }^{72}$ This result was in total agreement with those previously reported (see above).

The first endo-diastereoselective 1,3-DC of the key precursors of these antiviral agents was achieved via silver(I)metalloazomethine ylide in the presence of acrylates derived 70 from $(R)$ - or $(S)$-methyl lactate $\mathbf{6 4}$. The diastereoselection was very high $(96 \%$ de $)$ and $77 \%$ of chemical yield. Enantiomerically enriched (+)-54 and (-)-54 forms were finally isolated in $96 \%$ ee and in $51-54 \%$ yield (overall yield from iminoester 63), after successive amidation and double 75 hydrolytic process. In spite of the small size of the substituents bonded around the stereogenic centre, it was demonstrated that the excellent stereocontrol was originated by the interaction of the lactate methyl groups and the phenyl residue of the starting iminoester. ${ }^{73}$ 8 


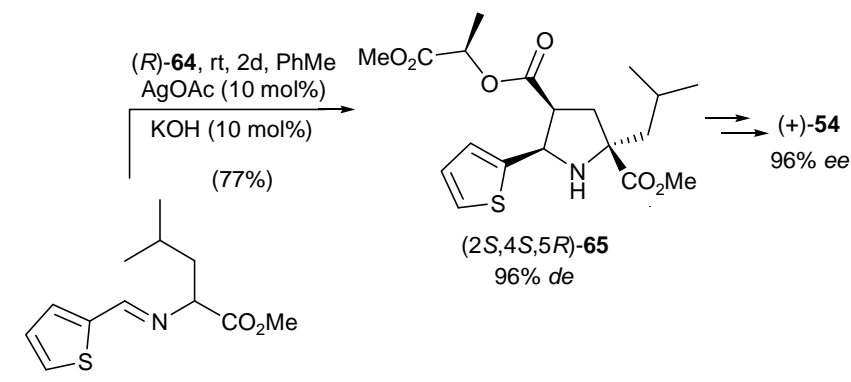

$\underset{\substack{\mathrm{KOH}(10 \mathrm{~mol} \%) \\ \text { AgOAc }(10 \mathrm{~mol} \%)}}{(77 \%)}$

$(2 R, 4 R, 5 S)$-ent-65 $96 \%$ de<smiles>C=CC(=O)O[C@@H](C)C(C)=O</smiles>

(R)-64<smiles>C=CC(=O)O[C@@H](C)C(C)=O</smiles>

(S)-64
Scheme 10. Diastereoselective synthesis of key compounds 65.

5 The more straightforward and faster approach to the enantiomeric forms of these non-nucleosidic antiviral agents is based on a catalytic enantioselective 1,3-DC as the key step. ${ }^{64}$ The asymmetric reaction was pioneered by Grigg and coworkers in 1991 using stoichimetric amounts of chiral bases 10 or chiral metal complexes. ${ }^{74}$ However, it was in 2002 just when the first substoichiometric catalytic (3 mol\%) enantioselective transformation was successfully reported by Zhang and coworkers using a chiral diphosphane/silver(I) complex. $^{75}$ At that time, this cycloaddition became a

15 fascinating transformation and many contributions appeared with outstanding results. Chiral metal complexes, chiral bases, and chiral organocatalysts have been tested obtaining the best results, in terms of diastereo- and enantioselectivities, and wider general scope when chiral metallodipoles were ${ }_{20}$ generated as intermediate products. Silver(I) ${ }^{76}$ and copper(I $)^{77}$ catalytic complexes afforded the most efficient and attractive processes. $^{78,79}$

The first enantioselective synthesis of the five-membered core of these structures was performed by using a chiral

25 phosphoramidite 67 and $\mathrm{AgClO}_{4}$ (both in $5 \mathrm{~mol} \%$ amounts) as catalyst. The reaction run at $-20{ }^{\circ} \mathrm{C}$ furnishes a good yield of compound endo-66 with a high enantioselection (Scheme 11, and Table 1, entry 1). In this work, the synthesis of enantiomerically enriched product $54(82 \%$ ee $)$ was also 30 reported after amidation and double hydrolytic sequence involving TFA $/ 0{ }^{\circ} \mathrm{C}$ followed by $\mathrm{KOH}-\mathrm{MeOH} / 80{ }^{\circ} \mathrm{C} .{ }^{76 \mathrm{j}, 80}$ Box ligand 68 and calcium isopropoxide formed a chiral complex, which was used to catalyse the process at -44 or $-30{ }^{\circ} \mathrm{C}$ in THF as solvent. The yields are high and the 35 enantioselectivities are the highest reported to date for compound 66 (85 and $88 \%$ ee) (Scheme 11 and Table 1, entries 2 and 3). ${ }^{78 d}$ Apart from the Lewis acid-catalysed 1,3DC the concept of organocatalysis was applied to the synthesis of 66 using hydroquinine 69 as quiral base (6 mol\%)
40 together with a $3 \mathrm{~mol} \%$ amount of silver acetate. Although chemical yields were very important, the enantioselection was moderate (74\% ee) (Scheme 11, and Table 1, entry 4). In fact, a further 1,1'-binaphthyl-2,2'-dihydrogen phosphate asisted chiral resolution of $\mathbf{6 6}$ was performed in order to obtain pure ${ }_{45}$ compound endo-66 with a $99.8 \% e e .^{79 \mathrm{~g}}$

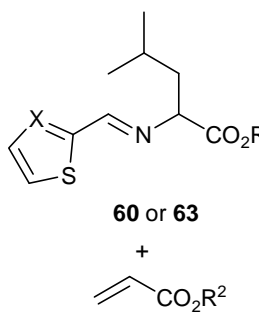

$\mathrm{X}=\mathrm{CH}, \mathrm{N}$

$\mathrm{R}^{1}=\mathrm{R}^{2}=\mathrm{Me}, \mathrm{Bu}^{\mathrm{t}}$
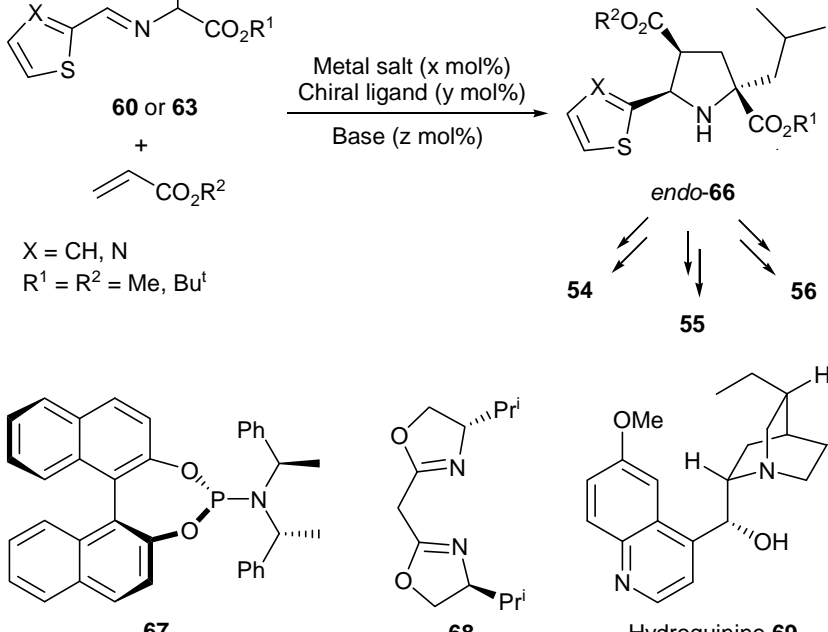

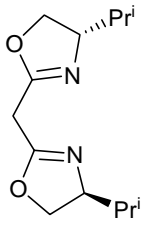

68

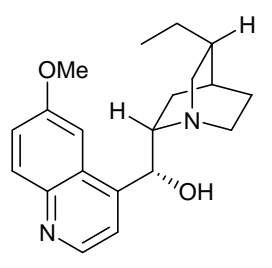

Hydroquinine 69
Scheme 11. Enantioselective synthesis of intermediate 66 .

${ }_{50}$ Table 1. Catalytic enantioselective synthesis of compound 66.

\begin{tabular}{|c|c|c|c|c|c|c|c|c|}
\hline$X$ & $\mathrm{R}^{1}$ & $\mathrm{R}^{2}$ & Salt $^{\mathrm{a}}$ & $\mathrm{L}^{\mathrm{a}}$ & Base $^{a}$ & $\mathrm{~T}\left({ }^{\circ} \mathrm{C}\right)$ & $\begin{array}{l}\text { Yield } \\
(\%)^{b}\end{array}$ & $e e(\%)$ \\
\hline $\mathrm{CH}$ & $\mathrm{Me}$ & $\mathrm{Bu}^{\mathrm{t}}$ & $\begin{array}{c}\mathrm{AgClO}_{4} \\
(5)\end{array}$ & $\begin{array}{l}67 \\
(5)\end{array}$ & $\begin{array}{c}\mathrm{Et}_{3} \mathrm{~N} \\
(5)\end{array}$ & 0 & 70 & 2 \\
\hline $\mathrm{CH}$ & $\mathrm{Bu}^{\mathrm{t}}$ & $\mathrm{Bu}^{\mathrm{t}}$ & $\begin{array}{c}\mathrm{Ca}\left(\mathrm{OPr}^{\mathrm{i}}\right)_{4} \\
(10)\end{array}$ & $\begin{array}{c}68 \\
(10)\end{array}$ & - & T7 & 83 & $85^{\mathrm{c}}$ \\
\hline $\mathrm{N}$ & $\mathrm{Bu}^{\mathrm{t}}$ & $\mathrm{Bu}^{\mathrm{t}}$ & $\begin{array}{c}\mathrm{Ca}\left(\mathrm{OPr}^{\mathrm{i}}\right)_{4} \\
(10)\end{array}$ & $\begin{array}{c}68 \\
(10)\end{array}$ & - & -30 & 83 & $88^{c}$ \\
\hline $\mathrm{N}$ & $\mathrm{Bu}^{\mathrm{t}}$ & $\mathrm{Me}$ & $\begin{array}{c}\mathrm{AgOAc} \\
(3)\end{array}$ & $\begin{array}{r}69 \\
(6) \\
\end{array}$ & - & 0 or -10 & 84 & 74 \\
\hline
\end{tabular}

${ }^{\mathrm{a}}$ In brackets (x, y or z mol\%). ${ }^{\mathrm{b}}$ Isolated yield. ${ }^{\mathrm{c}}$ ent-66 was obtained.

To the best of our knowledge the synthesis of antiviral agent 57 has not been reported yet, ${ }^{81}$ and it appeared as a 55 consequence of evolutive structural modifications of the precedent inhibitors, namely potency of the molecule, cell penetration and pharmacokinetics. Product 57 (GSK625433) is the most potent and selective drug having a good pharmacokinetic profile in phases I and II. This last 60 compound does not inhibit human DNA polymerases, can be administrated in low concentrations and no significant cytotoxicity was observed. ${ }^{82}$ The discovery of the active specific interaction site polymerase-receptor for the inhibitors supports this new trend of therapy. A small modification in ${ }_{65}$ the final structure of 57 can be translated in a more potent inhibition of the named viral polymerase, the highest optical purity of intermediate $\mathbf{6 6}$ being modulated by selecting the most appropriate solvent, silver salt, chiral ligand, temperature, and base.

70 This alternative therapy is orally administrated in smaller 
amounts, it is more inexpensive and causes much less side effects and complications than the current subcutaneous pegylated $\alpha$-interferon treatment combined with oral ribavirin. In addition, RNA-polymerase inhibition is much more 5 effective than the inhibition of other structural and nonstructural viral proteins in the fight against $\mathrm{HCV}$.

\section{Nitrile oxides}

Similarly to azomethine ylides, nitrile oxides $\mathbf{7 1}$ have to be generated in situ. There are many methods described for their preparation, ${ }^{7 \mathrm{~d}}$ dehydrohalogenation of hydroxymoyl chlorides 70 and dehydration of nitroalkanes being the most frequently 15 used strategies. The regioselectivity of the 1,3-DC of nitrile oxides and alkenes or alkynes is easily predictable. For monosubstituted alkenes and electrophilic olefins major regioisomer isoxazoles or isoxazolines ${ }^{48} \mathbf{7 2 a}$ and $\mathbf{7 2 b}$ are, respectively, isolated as pure compounds (Scheme 12). At 20 maximum, only two stereogenic centres can be generated employing catalytic enantioselective synthesis.

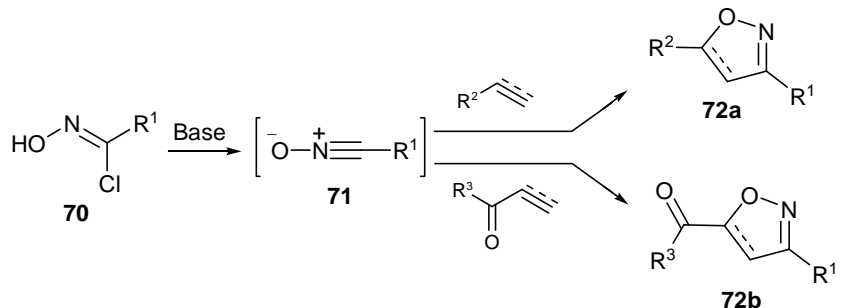

Scheme 12. Synthesis of the major regioisomers 72 .

As well as it was described previously for azides, nitrile oxides are used to strategically modify several parts of the molecule with the aim to increase its antiviral potency. Initial contributions were designed for studying the antiviral activity 30 of a series of products, but any biological results of essays was detailed. ${ }^{83}$ That was the case of C-nucleoside analogues $\mathbf{7 3}^{84}$, and isoxazolines $\mathbf{7 4} 4^{85}$ (Figure 10), which were obtained following the conditions depicted on Scheme 12 but using an $\alpha$-bromoacrylic system. ${ }^{86}$ They have a potential activity 35 against varicella-Zoster virus (VZV), cytomegalovirus (CMV), and herpes simplex virus (HSV). Particularly, compound 73, obtained from $\mathrm{N}$-vinylpurines, was moderately effective against HIV-1 in acutely infected primary human lymphocytes. ${ }^{84} \mathrm{~N}$-Oxide carbonocyanidic acid ethyl ester 40 reacted with benzodiazepines to yield compounds $\mathbf{7 5}$ that are considered as HIV reverse transcriptase inhibitors. ${ }^{87} \mathrm{~N}$ Adamanthyl isoxazoline $\mathbf{7 6}$ is a very simple structure that showed a slight inhibition of HIV. ${ }^{88}$ Since this publication, several articles reported modified structures able to hamper 45 the development of HIV. For example, nucleoside and nucleotides 77 and $78(n=1)$ (Figure 10) were obtained from the nitrile oxide and the corresponding $N$-vinylnucleo-base. The results were very promising against $\operatorname{HIV}, \mathbf{7 8}(\mathrm{n}=1)$ being the most effective and less cytotoxic drug. ${ }^{89}$ The connection of 50 oxygen and nitrogen atoms provided a possibility to introduce the nucleophilic nitrogen into the furanose ring with a minimum of steric manipulation, providing opportunities to modify the furanose ring of nucleoside analogues with novel structural features. Consequently, it became possible to design 55 other related $\mathrm{N}, \mathrm{O}$-containing derivatives for biological studies.

However, homologue compounds $78(\mathrm{n}=0)$ (Base $=$ thymine, fluorouracil, or cytosine) and $\mathbf{7 9}$ (Base = thymine) (Figure 10) completely inhibited the reverse transcriptase 60 activity of the avian myeloblastosis retrovirus at $10 \mu \mathrm{M}$ concentration. These isoxazolines $\mathbf{7 8}$, and $\mathbf{7 9}$ exhibited lower potency with respect to isoxazolidine derivatives $\mathbf{4 0}$, and $\mathbf{4 1}$ (Figure 8). ${ }^{90}$ The lesser ability to elicit recognition by the reverse transcriptase, due to the insertion of a double bond in ${ }_{65}$ the five-membered heterocycle, can be attributed to a lower molecular flexibility and a lower basicity of the nitrogen atom. Such as it was already mentioned, the bivalent metallic ions assisted the insertion of nucleotides in the growing nucleic acid chain. In this particular case, $\mathrm{Mg}^{+2}$ could form a 70 six-membered chelate with the nitrogen atom and the oxygen of the phosphorous group as well. ${ }^{90}$

The 1,3-DC involving nitrile oxides and alkynes (methyl propiolate) was studied in the generation of isoxazoles and isothiazoles $\mathbf{8 0}$ and $\mathbf{8 1}$, respectively. These aryl-substituted 75 heteroaromatic carboxylic acids (when $\mathrm{R}=3-\mathrm{BnO}$ in $\mathbf{8 0}$, and $\mathrm{R}=4-\mathrm{NO}_{2}$ in 81) afforded advantageous features of improvement of antiviral potency against HIV-1 integrase and decreased cytotoxicity with high therapeutic index. The good antiviral potency of the heteroaromatic carboxylic acid series 80 could be attributable to the improved bioavailability of the bioisosteres. On the other hand, the inconsistency between integrase inhibitory activity and the antiviral effect might involved multiple targeting in the HIV-1 life cycle. ${ }^{91}$

Finally, 2-deoxyuridine derivatives 82 (Figure 10), formed 85 by 1,3-DC of nitrile oxides and 5-alkynyluridines showed a poor affinity for HSV-1-specific thymidine kinase. ${ }^{92,93}$ 
<smiles>[R]c1cccn2c(C3CC(CO)=NO3)cnc12</smiles><smiles>[R]C(=O)C1CC([Al])=NO1</smiles>

74<smiles></smiles>

75<smiles>BrC1ON=C(c2ccccc2)N1C1C2CC3CC(C2)CC1C3</smiles>

76<smiles>OCC1=NOC(C(=[18O])[18OH])C1</smiles>

77<smiles>CCCCCCCC1CC(CP(=O)(OCC)OCC)=NO1</smiles>

79<smiles>[R]c1ccc(-c2cc(C(=O)O)sn2)cc1</smiles>

81<smiles>CCOP(=O)(NCC1=NOC(CBr)C1)OCC</smiles>

$78(n=0,1)$<smiles>[R]c1ccc(-c2cc(C(=O)O)on2)cc1</smiles>

80<smiles>[R1]c1cc(-c2cn(C3C[C@H](O)[C@@H](CO)O3)c(=O)[nH]c2=O)on1</smiles>

82
Base $=$ Purine or pyrimidine derivatives

Figure 10. Antiviral products derived from 1,3-DC between nitrile oxides and alkenes.

\section{${ }_{5} 6$. Diazoalkanes and carbonyl ylides}

For a long time diazo-compounds $\mathbf{8 3}$ have been one of the most synthetically useful classes of 1,3-dipoles because they could be prepared and isolated in pure form in contrast o 10 another 1,3-dipoles that are generated as transient species. ${ }^{7 \mathrm{~d}}$ The cycloadditions with double or triple bonds (including heteroatoms) have been widely surveyed (Scheme 13). ${ }^{7}$ The reaction with electrophilic olefins occurred such as it is depicted in Scheme 13, the carbon atom reacted at the 415 position of the electrophile with almost total selectivity to yield pyrazoline or pyrazole derivatives $\mathbf{8 4}$ and $\mathbf{8 5}$, nevertheless, some mixtures are obtained by reaction with electron-rich alkenes. In addition, the reaction of diazoalkanes with nitriles also give good regioselectivities of the 20 corresponding compounds 85 (Scheme 13).

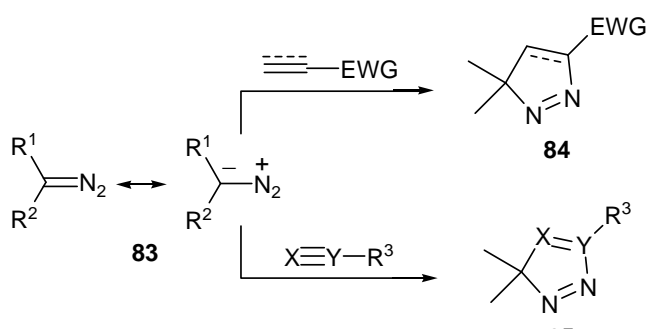

85

Scheme 13. General 1,3-DC promoted by diazoalkanes a safe, non-explosive and non-mutagenic substitute of diazomethane, and its cycloaddition can be greatly expanded by metallation with butyllithium. In general, $\Delta^{1}$-pyrazolines or pyrazoles 84 or $85^{94}$ were regioselectively obtained at very

30 low or room temperature (Scheme 13). In some occasions, the five membered ring is not the active substance but the corresponding cyclopropane, generated via photoinduced elimination of molecular nitrogen.

Thus, 2',3'-dideoxy-2',3'- $\alpha$-methanocytidine $\mathbf{8 8}$ was 35 prepared following this last mentioned sequence where the key intermediate 87 was regioselectively obtained in $84 \%$ yield and almost total diastereoselection. Product $\mathbf{8 8}$ only exhibited weak to moderate activity against the $\mathrm{HIV}^{95}$ (Scheme 14).

40

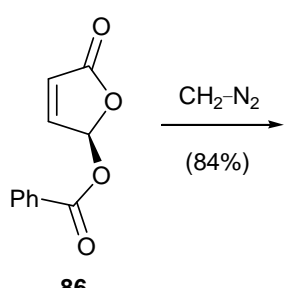

86

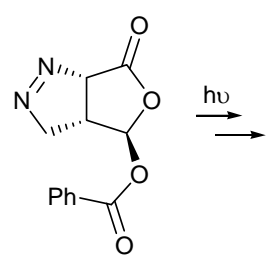

87<smiles>Nc1ccn([C@@H]2O[C@H](CO)[C@H]3C[C@H]32)c(=O)n1</smiles>

88
Scheme 14. Synthesis of antiviral agents 87 and $\mathbf{8 8}$.

$\Delta^{1}$-Pyrazoline 90 was diastereoselectively obtained ( $>99: 1$ $\left.{ }_{45} d r\right)$ in quantitative yield. This heterocycle was aromatised to yield the corresponding pyrazole unit with some interesting weak inhibition of several types of viruses (Scheme 15). ${ }^{96}$
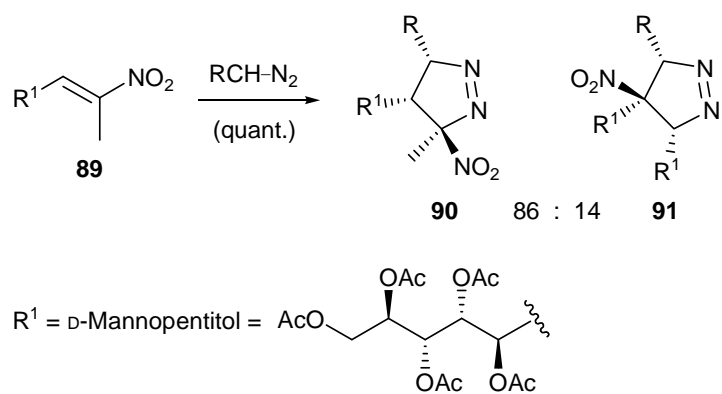

${ }_{50}$ Scheme 15. Synthesis of heteocycle $\mathbf{9 0}$.

The synthesis of pyrazole-5-carboxamide 95 started with the 1,3-DC between 1-(diazomethyl)-D-allitol derivative 92 and butynoate 93. Compound $\mathbf{9 4}$ underwent very simple and 55 standard reaction transformations to yield finally carboxamide 95 (Scheme 16). Analogously, amide 96, possessing the truncated acyclic side chain of acyclovir, was prepared in a similar manner. Both pyrazoles 95 and $\mathbf{9 6}$ demonstrated a weak biological activity against HIV, yellow fever virus, and 60 vaccine virus. ${ }^{97}$

25 The commercially available diazo(trimethylsilyl)methane is 


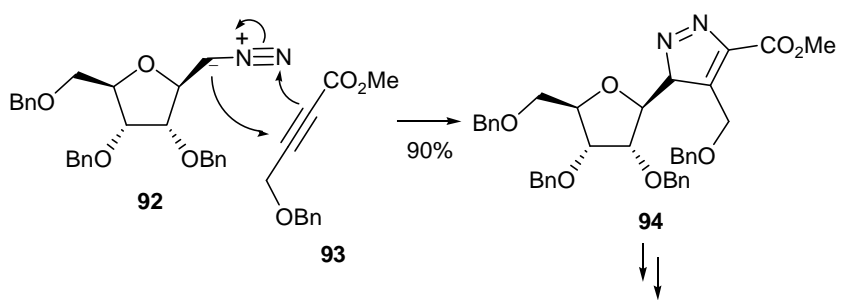<smiles>NC(=O)C1=C(CO)C([C@@H]2O[C@H](CO)[C@@H](O)[C@H]2O)N=N1</smiles>

95<smiles>NC(=O)c1[nH]nc(COCCO)c1CO</smiles>

96

Scheme 16. Synthesis of pyrazoles 94-95.

Diazo-compounds 98 were allowed to react with coumarins ${ }_{5} \mathbf{9 7}$, bearing a nitrile functional group, yielding products 99 in very good yields (73-85\%). After several steps coumarins 100 and the analogous adducts $\mathbf{1 0 1}$ were isolated. Compounds $\mathbf{1 0 1}$ showed encouraging results by inhibition of HIV-1 with an $\mathrm{IC}_{50}$ value $>0.17 \mu \mathrm{M}$, whilst none of the tested compounds $10 \mathbf{1 0 0}$ was found to inhibit HIV-1 or HIV-2 replication. The structure-activity relationship (SAR) suggested that molecules incorporating the carbon-coumarin linkage manifested a higher HIV inhibition activity than that of the corresponding analogues having the oxygen linkage as structures $\mathbf{1 0 0} .^{98}$

15 These results would lead to modify the target molecules by the introduction of more potential groups with a carbon linkage.<smiles>N#CCOc1ccc2oc(=O)ccc2c1</smiles>

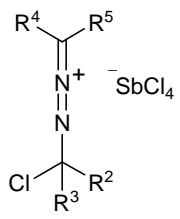

98<smiles>[R]c1cc(OCc2nc([R])n([R7])n2)cc2oc(=O)ccc12</smiles>

99<smiles>[R1]c1nc(Cc2cc(OC)c3ccc(=O)oc3c2)n([R])n1</smiles>

Scheme 17. Synthesis of series of compounds 100 and 101. compounds with antiviral activity was published employing a 25 1,3-DC between in situ generated carbonyl ylides and alkenes. In this work tetrahydrofuranyl glycine $\mathbf{1 0 4}$ have been obtained in 65\% yield from L-vinylglycine 102 through a 1,3-DC reaction using the non-stabilised carbonyl ylide, prepared from carcinogenic bis(chloromethyl) ether 103. The reaction 30 was run at $0{ }^{\circ} \mathrm{C}$ achieving better chemical yield of a 57:43 mixture of diastereoisomers (Scheme 18). ${ }^{99}$ The resulting polypeptides, incorporating this $\alpha$-amino acid $\mathbf{1 0 4}$, acted as substrate-based inhibitors of HIV-1 protease. The inhibitory action of these macromolecules was probably due to the 35 favourable interactions at the S2 region of neuraminidase (see above). This strategy proved to be very valuable to medicinal and peptide chemistry due to the numerous modifications to essay.

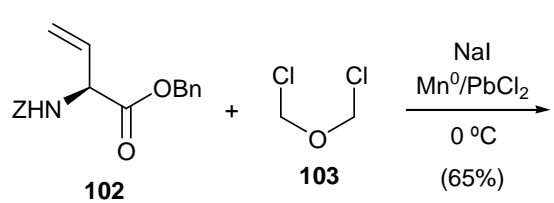<smiles>[Y]N[C@H](C(=O)OCc1ccccc1)[C@H]1CCOC1</smiles>

Scheme 18. 1,3-DC involving a carbonyl ylide as 1,3-dipole.

\section{Conclusions}

45

After more than a century after their discovery, these 1,3DCs represent a powerful tool in modern synthetic chemistry whose limits are still being explored. According to the previously described contents and in the search of drugs with ${ }_{50}$ the wider spectrum of activity, a clear perspective can be defined: the 1,3-DCs allow structural simple modifications, which fits to Lipinki's rules, facilitating the interaction drugvirus at different stages. Ylides are easily generated, the reactions involved are highly regio- and diastereoselective, 55 even with elevated enantioselection for enantioselective processes. The reaction conditions are usually very mild and the atom economy is almost total. Azides, nitrones, and azomethine ylides are the most employed dipoles giving rise to nitrogenated five membered ring heterocycles. Particularly 60 interesting is the enantioselective approach to them using substoichiometric amounts of chiral catalysts.

The most promising methodology is based on the azomethine ylide and its reactions with alkenes. In fact, this cycloaddition is a light of hope for the more of 190 million ${ }_{65}$ people having chronical hepatitis $\mathrm{C}$ in the world. This asymmetric reaction would allow to prepare multiple libraries of chiral molecules able to inhibit the HCV replication. The scope of these products can be also applied to the single or combined treatment of the HIV/HCV coinfected people (15 70 million of patients in a critical situation) or for the treatment of influenza or other devastating viruses, however, we have not any data about all these ambitious goals.

\section{Acknowledgments}

To the best of our knowledge only one example of 75 This work has been supported by the DGES of the Spanish 
Ministerio de Educación y Ciencia (MEC) (Consolider INGENIO 2010 CSD2007-00006, CTQ2007-62771/BQU, and CTQ2004-00808/BQU), and by the University of Alicante.

\section{${ }_{5}$ Notes and references}

${ }^{a}$ Departamento de Química Orgánica and Instituto de Síntesis Orgánica, Facultad de Ciencias, Universidad de Alicante 03080-Alicante (Spain) Fax:+34-965903549. E-mail: cnajera@ua.es and jmsanano@ua.es

\section{1 http://www.who.int/en/}

2 During the elaboration of this perspective two outbreaks were alerted. Uganda was the latest African country to be struck with a Marburg viral outbreak and, in other side Mexico took drastic measures to contain a new strain of the swine flu virus H1N1 at the end of April 2009.

J. D. Burke, E. N. Fish, Curr. Mol. Pharmacol., 2009, 2, 32-39.

4 M. D. de Jong, T. T. Tran, H. K. Truong, M. H. Vo, G. J. Smith, V. C. Nguyen, V. C. Bach, T. Q. Phan, Q. H. Do, Y. Guan, J. S. Peiris, T. H. Tran, J. Farrar, N. Engl. J. Med., 2005, 353, 2667-2672.

D. Lednicer, in Strategies for Organic Drug Synthesis and Design, Wiley-VCH, New Jersey, 2009.

6 The original Hüisgen cycloaddition was performed with azides as 1,3-dipole: R. Hüisgen, Angew. Chem. Int. Ed. Engl., 1963, 10, $565-$ 598.

For reviews dealing with general 1,3-dipolar cycloadditions, see: (a) A. Padwa, S. K. Bur, Tetrahedron, 2007; (b) V. Nair, T. D. Suja, Tetrahedron, 2007, 63, 12247-12275; (c) S. Sankararaman, in Pericyclic Reactions-A Textbook, Wiley-VCH, Weinheim, 2005; (d) A. Padwa, W. H. Pearson, in Synthetic Applications of 1,3-Dipolar Cycloaddition Chemistry Towards Heterocycles and Natural Products, John Wiley \& Sons, New Jersey, 2003; (e) S. Kobayashi, K. A. Jørgensen, in Cycloaddition Reactions in Organic Synthesis, Wiley-VCH, Weinheim, 2002; (f) S. Kanemasa, Synlett, 2002, 13711387.

8 I. Fleming, in Frontier Orbitals and Organic Chemical Reactions, John Wiley \& Sons, Chichester, 2002.

9 For additional examples concerning more complex heterocycles, see: (a) F. Casu, M. A. Chiacchio, R. Romeo, G. Gumina, Curr. Org. Chem. 2007, 11, 1017-1032; (b) S. G. Pyne, M. Tang, Curr. Org. Chem., 2005, 9, 1393-1418; (c) K. Nagasawa, Y. Hashimoto, Chem. Record, 2003, 3, 201-211.

10 The 1,3-DC is currently included in the academically incorrect concept known as "click reaction", for some representative reviews see: (a) A. D. Moorhouse, J. E. Moses, Chem. Med. Chem., 2008, 3, 715-723; (b) D. Fournier, R. Hoogenboom, U. S. Schubert, Chem. Soc. Rev., 2007, 36, 1369-1380; (c) B. de Droumaghet, K. Velonia, Macromol. Rapid Commun., 2008, 29, 1073-1089; (d) J. E. Moses, A. D. Moorhouse, Chem. Soc. Rev., 2007, 36, 1249-1262.

11 Click chemistry was initially proposed by: H. C. Kolb, M. G. Finn, K. B. Sharpless, Angew. Chem. Int. Ed., 2001, 40, 2004-2021.

12 The obtained products easily fit "the rule of 5", which stimates the solubility and permeability in drug discovery and development settings on the basis of experimental and computational approaches: C. A. Lipinski; F. Lombardo, B. W. Dominy, P. J. Feeney, Adv. Drug Delivery Rev., 2001,46, 3-26.

13 (a) P. Demko, K. B. Sharpless, Angew. Chem. Int. Ed. 2002, 41, 2110-2113; (b) P. Demko, K. B. Sharpless, Angew. Chem. Int. Ed. 2002, 41, 2113-2116.

14 (a) C. W. Tornoe, C. Christensen, M. Medal, J. Org. Chem. 2002, 67, 3057-3064; (b) V. V. Rostovtsev, L. G. Green, V. Fokin, K. B. Sharpless, Angew. Chem. Int. Ed., 2002, 41, 2596-2599.

15 For recent reviews dealing with applications of organic azides, see: (a) S. V. Chapyshev, Synlett, 2009, 1-8; (b) G. C. Tron, T. Pirali, R. A. Billington, P.-L. Canonico, G. Sorba, A. A. Genazzani, Med. Res. Rev., 2008, 28, 278-308; (c) G. Frank, A. Kakkar, Chem. Commun., 2008, 5267-5276; (d) R. J. Pieters, D. T. S. Rijkers, R. M. J. Liskamp, QSAR Comb. Sci., 2007, 26, 1181-1190; (e) Y. L. Angell,
K. Burguess, Chem. Soc. Rev., 2007, 36, 1674-1689; (f) J.-F. Lutz, Angew. Chem. Int. Ed., 2007, 46, 1018-1025; (g) F. SantoyoGonzález, F. Hernández-Mateo, Top. Heterocycl. Chem, 2007, 7 133-177; (h) I. Aprahamian, O. S. Miljanic, W. R. Dichtel, K. Isoda, T. Yasuda, T. Kato, J. F. Stoddart, Bull. Chem. Soc. Jpn., 2007, 80 1856-1869; (i) S. Dedola, S. A. Nepogodiev, R. A. Field, Org. Biomol. Chem., 2007, 5, 1006-1017; (j) W. H. Binder, C. Kluger, Curr. Org. Chem., 2006, 10, 1791-1815;

$16 \quad$ 1,2,3-Triazoles and benzotriazoles are important types of heterocyclic compounds. They find numerous applications in industry medicine and agrochemicals. A. C. Tome, Science of Synthesis, 2004, 13, $415-$ 601.

17 D. Haebich, W. Barth, M. Roesner, Heterocycles, 1989, 29, $2083-$ 2088.

18 D. Haebich, Synthesis, 1992, 358-360.

19 (a) R. Álvarez, S. Velázquez, A. San-Félix, S. Aquaro, E. De Clercq, C.-F. Perno, A. Karlsson, J. Balzarini, M. J. Camarasa, J. Med. Chem., 1994, 37, 4185-4194; (b) A. San-Félix, R. Álvarez, S. Velázquez, E. De Clerck, J. Balzarini, M. J. Camarasa, Nucleosides and Nucleotides, 1995, 14, 595-598.

20 (a) K. Yamashita, T. Oshikawa, S. Kazumichi, JP08245666, 1996; (b) K. Yamashita, T. Oshikawa, S. Kazumichi, JP08245667, 1996.

21 K. Danel, L. M. Larsen, E. B. Pedersen, G. Sanna, P. La Colla, R. Loddo, Bioorg. Med. Chem., 2008, 16, 511-517.

22 (a) A. Brik, J. Muldoon, Y.-C. Lin, J. H. Elder, D. S. Goodsell, A. J. Olson, V. V. Fokin, K. B. Sharpless, C.-W. Wong, ChemBioChem., 2003, 4, 1246-1248; (b) A. Brik, J. Alexandratos, Y.-C. Lin, J. H. Elder, A. J. Olson, A. Wlodawer, D. S. Goodsell, C.-H. Wong, ChemBioChem., 2005, 6, 1167-1169.

23 M. Whiting, J. Muldoon, Y.-C. Lin, S. M. Silverman, W. Lindstrom, A. J. Olson, H. C. Kolb, M. G. Finn, K. B. Sharpless, J. H. Elder, V. V. Fokin, Angew. Chem. Int. Ed., 2006, 45, 1435-1439.

24 M. J. Giffin, H. Heaslet, A. Brik, Y.-C. Lin, G. Cauvi, C.-H. Wong, D. E. McRee, J. H. Elder, C. D. Scout, B. E. Torbett, J. Med. Chem. 2008, 51, 6263-6270.

25 (a) H. Ding, R. Yang, Y. Song, Q. Xiao, J. Wu, Nucleosides, Nucleotides and Nucleic Acids, 2008, 27, 368-375. (b) J. Wang, H. Li, G. Zou, L.-X. Wang, Org. Biomol. Chem.., 2007, 5, 1529-1540.

26 H. Gopi, M Umashankara, V. Pirrone, J. Lalonde, N. Madani, F. Tuzer, S. Baxter, I. Zentner, S. Cocklin, N. Jawanda, S. R. Miller, A. Schön, J. C. Klein, E. Freire, F. C. Krebs, A. B. Smith, J. Sodroski, I. Chaiken, J. Med. Chem. 2008, 51, 2638-2647.

27 J. Li., M. Zheng, W. Tang, P.-L. He, W. Zhu, T. Li, J.-P. Zuo, H. Liu, H. Jiang, Bioorg. Med. Chem. Lett. 2006, 16, 5009-5013.

28 Y. Lu, J. Gervay-Hague, Carbohydr. Res. 2007, 342, 1636-1650.

29 A. Marra, L. Moni, D. Pazzi, A. Corallini, D. Bridi, A.Dondoni, Org. Biomol. Chem., 2008, 6, 1396-1409.

30 U. Pradere, V. Roy, T. R. McBrayer, R. F. Schinazi, L. A. Agrofolio, Tetrahedron, 2008, 64, 9044-9051.

31 G. Godeau, C. Staedel, P. Barthélémy, J. Med. Chem., 2008, 16, 8427-8439.

32 P. Chittepu, V. R. Sirivolu, F. Seela, Bioorg. Med. Chem., 2008, 16, 8427-8439.

33 A.-G. Ahmed, A. A.-H. Abdel-Rahman, I. F. Zeid, E. E.-D. Salem, A. A. Ranouf, Mansouda J. Chem., 2006, 33, 105-116.

34 A.-G. Ahmed, A. A.-H. Abdel-Rahman, I. F. Zeid, E. E.-D. Salem, A. A. Ranouf, Mansouda J. Chem., 2006, 33, 87-103.

35 O. Moukha-Chafiq, M. L. Taha, H. B. Lazrek, J.-L. Barascut, J.-L. Imbach, Comptes-Ren. Acad. Sci., Series IIC: Chim, 2000, 3, 639641 .

36 O. Moukha-Chafiq, M. L. Taha, H. B. Lazrek, C. Pannecoucque, M. Witvrouw, E. De Clercq, J.-L. Barascut, Nucleosides, Nucleotides \& Nucleic acids, 2001, 20, 1797-1810.

37 (a) J. Broggi, N. Joubert, S. Díez-González, T. Zebaco, S. BerteinaRaboin, S. Nolan, D, Topalis, D. Deville-Bonne, J. Balzarini, J. Neyts, G. Andrei, R. Snoeck, L. A. Agrofoglio, Nucleosides, Nucleotides \& Nucleic Acids, 2004, 26, 1391-1394.; (b) J. Broggi, N. Joubert, S. Díez-González, S. Berteina-Raboin, T. Zevaco, S. Nolan, L. A. Agrofoglio, Tetrahedron, 2009, 65, 1162-1170. 
38 I. Pérez-Castro, O. Caamaño, F. Fernández, M. D. García, C. López, E. De Clercq, Org. Biomol. Chem., 2007, 5, 3805-3813.

39 W.-H. Zhan, H. N. Barnhill, K. Sivakumar, H. Tian, Q. Wang, Tetrahedron Lett., 2005, 46, 1691-1695.

40 M. A. Bruckman, G. Kaur, L. A. Lee, F. Xie, J. Sepúlveda, R. Breitenkamp, X. Zhang, M. Joralemon, T. P. Russell, T. Emrick, Q. Wang, ChemBioChem., 2008, 9, 519-523.

41 J. Rong, L. A. Lee, K. Li, B. Harp, C. M. Mello, Z. Niu, Q. Wang, Chem. Commun., 2008, 5185-5187.

42 E. Arstad, C. J. Steel, PCT Int. Appl. 2007, WO2007148074.

43 G. Guichard, S. Fournel, N. Trouche, S. Wieckowski, PTC Int. Appl. 2008, WO2008110695.

44 C. Cai, C. M. Yam, J. Gu, US Pat. Appl. Publ., 2009, US2009082222.

45 B. G. De Geest, W. van Camp, F. E. Du Prez, S. C. De Smedt, J. Demeester, W. E. Hennink, Macromol. Rapid. Commun., 2008, 29, 1111-1118.

46 (a) J. Revuelta, S. Cicchi, A. Goti, A. Brandi, Synthesis, 2007, 485504; (b) P. Merino, Science of Synthesis, 2004, 27, 511-580.

47 (a) Hyrosova, L. Fisera, M. Medvecky, H.-U. Reissing, A. AlHarrasi, M. Koos, Arkivoc, 2009, ix, 122-142; (b) I. A. Grigor'ev, in "From Nitrile Oxides, Nitrones and Nitronates in Organic Synthesis », Ed. H. Feuer, $2^{\text {nd }}$ Ed., John Wiley \& Sons Inc., New Jersey, 2008, 129-434; (c) R. A. Floyd, R. D. Kopke, C.-H. Choi, S. B. Foster, S. Doblas, R. A. Towner, Free Radic. Biol. Med., 2008, 45, 1361-1374.

48 S. Cicchi, F. M. Cordero, D. Gioni, Progress in Heterocycl. Chem., 2003, 15, 261-283.

49 U. Chiacchio, A. Corsano, D. Iannazzo, A. Piperno, V. Pistará, A. Procopio, A. Rescifina, G. Romero, R. Romero, M. C. R. Siciliano, E. Valveri, Arkivoc, 2002, xi, 159-167.

50 A. Leggio, A. Liguori, A. Procopio, C. Siciliano, G. Sindona, Tetrahedron Lett., 1996, 37, 1277-1280.

51 (a) G. Giglio, A. Napoli, A. Leggio, A. Liguori, A. Procopio, C. Siciliano, G. Sindona, Synth. Commun., 1996, 26, 4211-4217; (b) A. Leggio, A. Liguori, A. Procopio, C. Siciliano, G. Sindona, Nucleosides, Nucleotides \& Nucleic Acids, 1997, 16, 1515-1526.

52 R. Dalpozzo, A. De Nino, L. Maiuolo, A. Procopio, G. De Munno, G. Sindona, Tetrahedron, 2001, 57, 4035-4038.

53 E. Colacino, A. Converso, A. Liguori, A. Napoli, C. Siciliano, G. Sindona, Tetrahedron, 2001, 57, 8551-8557.

54 U. Chiacchio, F. Genovese, D. Iannazzo, A. Piperno, P. Quadrelli, C. Antonino, R. Romeo, V. Valveri, A. Mastino, Bioorg. Med. Chem., 2004, 12, 3903-3909.

55 A. Procopio, S. Alcaro, A. De Nino, L. Mainolo, F. Ortuso, G. Sindona, Bioorg. Med. Chem. Lett., 2005, 15, 545-550.

56 U. Chiachio, E. Balesterini, B. Macchini, D. Iannazzo, A. Piperno, A Rescifina, R. Romeo, M. Saglimbeni, M. T. Sciortino, V. Valveri, A. Mastino, G. Romeo, J. Med. Chem., 2005, 48, 1389-1394.

57 U. Chiacchio, D. Iannazzo, A. Piperno, R. Romeo, G. Romeo, A. Rescifina, M. Sglimbeni, Bioorg. Med. Chem., 2006, 14, 955-939.

58 A. Rescifina, M. A. Chiacchio, A. Corsano, E. De Clercq, D. Iannazzo, A. Mastino, A. Piperno, G. Romeo, R. Romeo, V. Valveri, J. Med. Chem., 2006, 49, 709-715.

59 E. Hyrosova, L. Fisera, R. M.-A. Jame, N. Pronayova, M. Medvecky, M. Koos, Chem. Heterocycl. Comp., 2007, 43, 10-17.

60 T. Mineno, M. J. Miller, J. Org. Chem., 2003, 68, 6591-6596.

${ }^{61}$ U. Chiacchio, A. Corsaro, D. Iannazzo, A. Piperno, V. Pistará, A. Rescifina, R. Romeo, V. Valverí, A. Mastino, G. Romeo, J. Med. Chem., 2003, 46, 3696-3702.

62 (a) A. Padwa, S. K. Bur, Tetrahedron, 2007, 63, 5341-5378; (b) H. Pellisier, Tetrahedron, 2007, 63, 3235-3285; (c) I. Coldham, R. Hufton, Chem. Rev., 2005, 105, 2765-2809, and references cited therein

63 (a) M. I. Calaza, C. Cativiela, Eur. J. Org. Chem., 2008, 3427-3448; (b) C. Nájera, J. M. Sansano, Chem. Rev., 2007, 107, 4273-4303; (c) P. Karoyan, S. Sagan, O. Lequin, J. Quancard, S. Lavielle, G. Chassaing Targets Heterocycl. Syst., 2004, 8, 216-273.

64 (a) C. Nájera, J. M. Sansano, Topics Heterocyclic Chem., Ed. A. Hassner 2008, 12, 117-145; (b) L. M. Stanley, M. P. Sibi, Chem.
Rev., 2008, 108, 2887-2902; (c) M. Álvarez-Corral, M. MuñozDorado, I. Rodríguez-García, Chem. Rev., 2008, 108, 3174-3198; (d) M. Naodovic, H. Yamamoto, Chem. Rev., 2008, 108, 3132-3148; (e) V. Nair, T. D. Suja, Tetrahedron, 2007, 63, 122247-12275; (f) G. Pandey, P. Banerjee, S. R. Gadre, Chem. Rev., 2006, 106, 4484-4517; (g) T. M. V. D. Pinho e Melo, Eur. J. Org. Chem., 2006, 2873-2888; (h) M. Bonin, A. Chauveau, L. Micouin, Synlett, 2006, 2349-2363; (i) C. Nájera, J. M. Sansano, Angew. Chem. Int. Ed., 2005, 44, 62726276; (j) S. Husinec, V. Savic, Tetrahedron: Asymmetry, 2005, 16, 2047-2061 and references cited therein.

65 These compounds are important in scientific areas such as peptide design, neuroexcitators and insecticides, as well as organocatalysts in organic synthesis.

66 T. L. Tellinghuisen, M. J. Evans, T. von Hahn, S. You, C. M. Rice, J. Virol., 2007, 81, 8853-8867.

67 R. Gish, "The HCV Advocate Medical Writers' Circle", February, 1 2006.

68 T. Swan, "Hepatitis C: New Treatments in the Pipeline" (Treatment Action Group, New York, April, 2008).

69 G. Burton, T. W. Ku, T. J. Carr, T. Kiesow, R. T. Sarisky, J.-L. Goerke, A. Baker, D. L. Earnshaw, G. A. Hofmann, R. M. Keenan, D. Dhanak, Bioorg. Med. Chem. Lett., 2005, 15, 1553-1556.

70 F. Pauwels, W. Mostmans, L. M. M. Quirynen, L. van der Helm, C. W. Boutton, A.-S. Rueff, E. Cleiren, P. Raboisson, D. Surleraux, O, Nyanguile, K. A. Simmen, J. Virol., 2007, 81, 6909-6919.

71 G. Burton, T. W. Ku, T. J. Carr, T. Kiesov, R. T. Sarisky, J. LinGoerke, G. A. Hofmann, M. J. Slater, D. Haigh, D. Dhanak, V. K. Johnson, N. R. Parry, P. Thomes, Bioorg. Med. Chem. Lett., 2007, 17, 1930-1933.

72 M. J. Slater, E. M. Amphlett, D. M. Andrews, G. Bravi, G. Burton, A. G. Cheasty, J. A. Corfield, M. R. Ellis, R. H. Fenwick, S. Fernandes, R. Guidetti, D. Haigh, C. D. Hartley, P. D. Howes, D. L. Jackson, R. L. Jarvest, V. L. H. Lovegrove, K. J. Medhurst, N. R. Parry, H. Price, P. Shah, O. M. P. Singh, R. Stocker, P. Thommes, C. Wilkinson, A. Wonacott, J. Med. Chem., 2007, 50, 897-900.

73 C. Nájera, M. G. Retamosa, J. M. Sansano, A. De Cózar, F. P. Cossío, Eur. J. Org. Chem., 2007, 5038-5049.

74 P. Allway, R. Grigg, Tetrahedron Lett.,1991, 32, 5817-5820.

75 J. M. Longmire, B. Wang, X. Zhang, J. Am. Chem. Soc., 2002, 124, 13400-13401.

76 a) C. Chen, X. Li, S. L. Schreiber, J. Am. Chem. Soc., 2003, 125, 10174-10175. b) T. F. Knöpfel, P. Aschwanden, T. Ichikawa, T. Watanabe, E. M. Carreira, Angew. Chem. Int. Ed., 2004, 43, 59715973; c) W. Zheng, Y.-G. Zhou, Org. Lett., 2005, 7, 5055-5058; d) R. Stohler, F. Wahl, A. Pfaltz, Synthesis, 2005, 1431-1436; e) W. Zheng,Y.-G- Zhou, Tetrahedron Lett., 2007, 48, 4619-4622; f) W. Zheng, G.-Y Chen, Y. G. Zhou, Y.-X. Li, J. Am. Chem. Soc., 2007, 129, 750-751; g) C. Nájera, M. G. Retamosa, J. M. Sansano, Org. Lett., 2007, 9, 4025-4028; h) C. Nájera, M. G. Retamosa, J. M. Sansano, Angew. Chem. Int. Ed., 2008, 47, 6055-6058; i) C. Nájera, M. G. Retamosa, J. M. Sansano, A. de Cózar, F. P. Cossío, Tetrahedron: Asymmetry, 2008, 19, 2913-2923; j) C. Nájera, M. Martín-Rodríguez, M. G. Retamosa, J. M. Sansano, A. de Cózar, F. P. Cossío,. Eur. J. Org. Chem., 2009, in press.

77 For copper(II)-catalysed 1,3-DC see: Y. Oderaotoshi, W. Cheng, S. Fujitomi, Y. Kasano, S. Minakata, M. Komatsu, Org. Lett., 2003, 5, 5043-5046.

For copper(I)-catalysed 1,3-DC see: a) W. Gao, X. Zhang, M. Raghunath, Org. Lett.,2005, 7, 4241-4244; b) S. Cabrera, R. GómezArrayás, J. C. Carretero, J. Am. Chem. Soc., 2005, 127, 1639416395.; c) T. Llamas, R. Gómez-Arrayás, J. C. Carretero, Org. Lett., 2006, 8, 1795-1798; d) X.-X. Yan, Q. Peng, Y. Zhang, K. Zhang, W. Hong, X.-L. Hou, Y.-D. Wu, Angew. Chem. Int. Ed., 2006, 45, 19791983; e) S. Cabrera, R. Gómez-Arrayás, B. Martín-Matute, F. P. Cossío, J. C. Carretero, Tetrahedron, 2007, 63, 6587-6602; f) B. Martín-Matute, S. I. Pereira, E. Peña-Cabrera, J. Adrio, A. M. S. Silva, J. C. Carretero, Adv. Synth. Catal., 2007, 349, 1714-1724; g) J.-W. Shi, J. W. Shi, Tetrahedron: Asymmetry, 2007, 18, 645-650; h) T. Llamas, R. Gómez-Arrayás, J. C. Carretero, Synthesis, 2007, 950957; i) C.-J. Wang, G. Liang, Z.Y. Xue, F. Gao, J. Am. Chem. Soc., 
2008, 130, 17250-17251; j) S. Fukuzawa, H. Oki, Org. Lett., 2008, 10, 1747-1750; k) A. López-Pérez, J. Adrio, J. C. Carretero, J. Am. Chem. Soc., 2008, 130, 10084-10085; 1) J. Hernández-Toribio, R. Gómez-Arrayás, B. Martín-Matute, J. C. Carretero, Org. Lett., 2009, 11, 393-396; m) A. López-Pérez, J. Adrio, J. C. Carretero, Angew. Chem. Int. Ed., 2009, 48, 340-343.

78 Another chiral metal complexes such as $\mathrm{Ni}^{\mathrm{II}}, \mathrm{Zn}^{\mathrm{II}}$, and $\mathrm{Ca}^{\mathrm{II}}$ have been tested: a) O. Dogan, H. Koyuncu, P. Garner, A. Bulut, W. J. Youngs, M. Panzner, Org. Lett., 2006, 8, 4687-4690; b) A. S. Gothelf, K. V. Gothelf, R. G. Hazell, K. A. Jørgensen, Angew. Chem. Int. Ed., 2002, 41, 4236-4238; c) J.-W. Shi, M.-X. Zhao, Z.-Y. Lei, M. Shi, J. Org. Chem., 2008, 73, 305-308; d) T. Tsubogo, S. Saito, K. Seki, Y. Yamashita, S. Kobayashi, J. Am. Chem. Soc., 2008, 130, 1332113332; e) S. Saito, T. Tsubogo, S. Kobayashi, J. Am. Chem. Soc., 2007, 129, 5364-5365.

79 The employment of organocatalysts as well as chiral bases has been reported: a) C. Alemparte, G. Blay, K. A. Jørgensen, Org. Lett., 2005, 7, 4569-4572; b) S. Arai, F. Takahashi, R. Tsuji, A. Nishida, Heterocycles, 2006, 67, 495-501; c) I. Ibrahem, R. Ríos, J. Vesely, A. Córdova, Tetrahedron Lett., 2007, 48, 6252-6257; d) J. L. Vicario, S. Reboredo, D. Badía, L. Carrillo, Angew. Chem. Int. Ed., 2007, 46, 5168-5170; e) R. C. Flanagan, S. Xie, A. Millar, Org. Process. Res. Develop., 2008, 12, 1307-1312; f) M.-X. Xue, X.-M. Zhang, L.-Z. Gong, Synlett, 2008, 691-694; g) A. A. Agbodjan, B. E. Cooley, R. C. B. Copley, J. A. Corfield, R. C. Flanagan, B. N. Glover, R. Guidetti, D. Haigh, P. D. Howes, M. M. Jackson, R. T. Matsuoka, K. J. Medhurst, A. Millar, M. J. Sharp, M. J. Slater, J. F. Toczko, S. Xie, J. Org. Chem., 2008, 73, 3094-3102; h) M. Nakano, M. Terada, Synlett, 2009, 1670-1675.

80 C. Nájera, M. G. Retamosa, J. M. Sansano, Spanish Patent Application: P200800908, May 2008.

81 www.CEN-ONLINE.ORG, May 7, 2007, p. 56

82 These data were obtained from ClinicalTrial.govid:NCT00439959, (December 2008).

83 J. M. Tronchet, A. Jottearand, N. Le Hong, F. Perret, S. ThorndahlJacqard, J. Tronchet, J. M. Chalet, L. Faivre, C. Hausser, C. Sebastian, Helv. Chim. Acta, 1970, 53, 1484-1489.

84 (a) Y. Xiang, J, Chen, R. F. Schinazi, K. Zhao, Bioorg. Med. Chem. Lett., 1996, 6, 1051-1054; (b) S. Pan, G. Wang, R. F. Schinazi, K. Zhao, Tetrahedron Lett., 1998, 39, 8191-8194.

85 Isoxazoles and benzoisoxazoles have shown marked action as antispasmodic, anesthetic, anti-inflammatory, antiviral, analgesic, antipyretic, anticoagulant and antirheumatic agents. (a) B. J. Wakefield, Science of Synthesis, 2004, 11, 229-288; (b) R. K. Smalley, Science of Synthesis, 2004, 11, 289-335.

86 S. Dadiboyena, J. Xu, A. T. Hamme, II., Tetrahedron Lett., 2007, 48, 1295-1298.

87 C. Goulaouic-Dubois, D. R. Adams, A. Chiaroni, C. Riche, F. W. Fowler, D. S. Grierson, Heterocycles, 1994, 39, 509-512.

88 A. Chimirri, S. Grasso, A. M. Monforte, P. Monforte, M. Zappala, A. Carotti, Farmaco, 1994, 49, 509-511.

89 H.-J. Gi, Y. Xiang, R. F. Schinazi, K. Zhao, J. Org. Chem., 1997, 62 , 88-92.

90 G. Romeo, D. Iannazzo, A. Piperno, R. Romeo, M. Saglimbeni, M. A. Chiacchio, E. Balesterini, B. Macchi, A. Mastino, Bioorg. Med. Chem., 2006, 14, 3818-3824.

91 L.-F. Zeng, H.-S. Zhang, Y.-H. Wang, T. Sánchez, Y.-T. Zheng, N. Neamati, Y.-Q. Long, Bioorg. Med. Chem. Lett., 2008, 18, 45214524.

92 I. Luiten, L. Jie, A. van Aershot, C. Pannecouque, P. Wigerinck, J. Rozenski, C. Hendrix, C. Wang, L. Wiebe, Antiviral Chem. Chemotherapy, 1995, 6, 262-270.

93 For other unsuccessful antiviral agents see: (a) J. Hu, Z.-F. Xie, Y.-H. Hui, X. X. Mo, X. Sun, F.-M. Liu, Chin. J. Org. Chem., 2007, 27, 1162-1166; (b) P.-Z. Zhang, X.-L. Li, H. Chen, Y.-N. Li, R. Wang, Tetrahedron Lett., 2007, 48, 7813-7816.

94 B. Stanovnik, J. Svete, Science of Synthesis, 2004, 12, 15-226.

95 A. R. Beard, P. I. Butter, J. Mann, N. K. Parlett, Carbohydr. Res., 1990, 205, 87-91.
96 M. Mancera, E. Rodríguez, I. Roffé, J. A. Galbis, C. F. Conde, A. Conde, Carbohydr. Res., 1991, 210, 327-322.

97 D. R. Sauer, S. W. Schneller, B. Gabrielsen, Carbohydr. Res., 1993, 241, 71-79.

98 Y. A. Al-Soud, J. A. Al-Masoudi, B. Saeed, U. Berfu $\beta$, N. A. AlMasoudi, Chem. Heterocycl. Comp., 2006, 42, 583-590.

99 S. Rajesh, E. Ami, T. Kotake, T. Kimura, Y. Hayashi, Y. Kiso, Bioorg. Med. Chem. Lett., 2002, 12, 3615-3617. 